\title{
Interleukin-21 promotes thymopoiesis recovery following hematopoietic stem cell transplantation
}

\author{
Aurélie Tormo ${ }^{1}$, Fatemeh Khodayarian ${ }^{1}$, Yun Cui ${ }^{1}$, Edouard Al-Chami ${ }^{1}$, Reem Kanjarawi ${ }^{1}$, Beatriz Noé1,
} Huijie Wang ${ }^{1}$ and Moutih Rafei ${ }^{1,2,3^{*}}$

\begin{abstract}
Background: Impaired T cell reconstitution remains a major deterrent in the field of bone marrow (BM) transplantation (BMT) due to pre-conditioning-induced damages inflicted to the thymi of recipient hosts. Given the previously reported thymo-stimulatory property of interleukin (IL)-21, we reasoned that its use post-BMT could have a profound effect on de novo $T$ cell development.

Methods: To evaluate the effect of IL-21 on de novo T cell development in vivo, BM derived from RAG2p-GFP mice was transplanted into LP/J mice. Lymphocyte reconstitution was first assessed using a hematological analyzer and a flow cytometer on collected blood samples. Detailed flow cytometry analysis was then performed on the BM, thymus, and spleen of transplanted animals. Finally, the effect of human IL-21 on thymopoiesis was validated in humanized mice.

Results: Using a major histocompatibility complex (MHC)-matched allogeneic BMT model, we found that IL-21 administration improves immune reconstitution by triggering the proliferation of $\mathrm{BM} \mathrm{Lin}{ }^{-} \mathrm{Sca}^{+}{ }^{+} \mathrm{C}-\mathrm{kit}{ }^{+}$(LSK) subsets. The pharmacological effect of IL-21 also culminates in the recovery of both hematopoietic (thymocytes) and nonhematopoietic (stromal) cells within the thymi of IL-21-treated recipient animals. Although T cells derived from all transplanted groups proliferate, secrete various cytokines, and express granzyme B similarly in response to T cell receptor (TCR) stimulation, full regeneration of peripheral naïve $C D 4^{+}$and $C D 8^{+} T$ cells and normal TCRv $\beta$ distribution could only be detected in IL-21-treated recipient mice. Astonishingly, none of the recipient mice who underwent IL-21 treatment developed graft-versus-host disease (GVHD) in the MHC-matched allogeneic setting while the graft-versustumor (GVT) effect was strongly retained. Inhibition of GVHD onset could also be attributed to the enhanced generation of regulatory B cells (B10) observed in the IL-21, but not PBS, recipient mice. We also tested the thymopoiesis-stimulating property of human IL-21 in NSG mice transplanted with cord blood (CB) and found significant improvement in de novo human $\mathrm{CD}^{+} \mathrm{T}$ cell development.
\end{abstract}

Conclusions: In sum, our study indicates that IL-21 represents a new class of unforeseen thymopoietin capable of restoring thymic function following BMT.

Keywords: IL-21, Hematopoietic stem cells, Thymopoiesis, Spleen, Graft-versus-host disease, Regulatory B cells, Graft-versus-tumor, Humanized mice

\footnotetext{
* Correspondence: moutih.rafei.1@umontreal.ca

${ }^{1}$ The Department of Pharmacology and Physiology, Université de Montréal,

2900 Edouard-Montpetit BLVD, Montréal, Québec H3T 1J4, Canada

${ }^{2}$ The Department of Microbiology, Infectious Diseases and Immunology,

Université de Montréal, 2900 Edouard-Montpetit BLVD, Montréal, Québec

H3T 1J4, Canada

Full list of author information is available at the end of the article
} 


\section{Background}

BMT is commonly used in the clinic as a curative therapy for a variety of life-threatening diseases of lymphohematopoietic origin [1-7]. Prior to BMT, patients undergo myeloablative or non-myeloablative conditioning regimens consisting of radiation, chemotherapy, and/ or administration of immunosuppressive drugs [1-7]. Although innate immunity mediated by myeloid and natural killer cells recovers relatively quickly in patients of all ages, $\mathrm{T}$ cell reconstitution requires years and even then rarely re-establishes a fully competent $\mathrm{T}$ cell repertoire [8-10]. This prolonged post-transplant lymphoid deficiency is associated with increased risks of (i) cancer relapse or development of secondary malignancies [11-17], (ii) infection [18-21], and (iii) reduced responses to immunotherapies such as vaccination [5, 22]. In line with this notion, a clinical study based on 42 mantle cell lymphoma patients who underwent BMT revealed that absolute lymphocyte count recovery is a powerful prognostic factor for clinical outcome [23]. Furthermore, accelerated lymphocyte recovery culminates in improved responses to immunebased treatments as previously achieved with the combined use of rituximab and BMT [23-26]. Thus, identifying factors capable of inducing de novo intrathymic $\mathrm{T}$ cell development (thymopoiesis) in patients undergoing BMT remains a central goal in the field.

IL-21 is the most recently identified member of the common $\gamma$-chain family of cytokines [27]. Some of its pleiotropic functions include (i) promoting Th17 differentiation in the presence of transforming growth factor$\beta$ [28], (ii) activating NK and CD8 lymphocytes [29, 30], (iii) desensitizing responder cells to the inhibitory effects of regulatory $\mathrm{T}$ cells (Tregs) [31], and (iv) acting as a switch for IgG production in B cells [32]. Although not required for hematopoiesis, in vivo expansion of bone marrow (BM) progenitors was observed in response to IL-21 overexpression [33]. Consistently, Simard et al. showed that IL-21 signaling in BM-derived B cell progenitors accelerates the development of immature/mature B cells by regulating the expression of Blimp1, Aid, and the germline transcript gamma $2 \mathrm{~b}$ [34]. For the $\mathrm{T}$ cell lineage, however, IL-21 is not necessary for thymocyte differentiation due to normal thymopoiesis in mice exhibiting an IL-21 receptor (IL-21R) deficiency [27, 32]. Paradoxically, we previously reported that TCR engagement on double-positive (DP) thymocytes triggers the de novo expression of IL-21R [35]. Although DP thymocytes undergo a three- to fourfold expansion in response to IL-21 treatment in vitro, no differentiation towards $\mathrm{CD}^{+}$single-positive (SP) T cells could be detected [35]. As no mitogen has ever been described for DP thymocytes, we then tested the thymopoiesis-stimulating ability of IL-21 in models of acute and chronic thymic atrophy. For instance, IL-21 administration to mice suffering from corticosteroid-induced thymic atrophy led to double-negative (DN) and DP thymocyte expansion, which resulted in accelerated recovery of thymic function [36]. In wild-type (WT) aged mice displaying naturally induced thymic atrophy, IL-21 enhanced the output of recent thymic emigrants (RTEs), which qualitatively changed the peripheral $\mathrm{T}$ cell pool [37]. On top of correcting several $\mathrm{T}$ cell defects commonly seen with aging such as impaired proliferation and biased cytokine production, an enhanced anti-tumoral response to a Trp2based melanoma cancer vaccine was achieved in aged mice pre-conditioned with IL-21 [37]. The overall significance of these findings epitomizes IL-21 as a potent pharmacological agent for stimulating thymopoiesis and serves as the basis to further investigate its use in $\mathrm{T}$ cell reconstitution following allogeneic BMT.

\section{Methods}

\section{Cell line and mice}

The P815 cell line was purchased from ATCC (Manassas, VA, USA). The RAG2p-GFP transgenic mice were kindly provided by Dr. M. Nussenzweig (Rockefeller University, NY, USA). C57BL/6 (H2-K ${ }^{\mathrm{b}}$ ), ${\mathrm{IL}-7^{-/}}^{-1}$ (C57BL/6 background, H2-K $\left.{ }^{\mathrm{b}}\right), \quad \mathrm{IL}-21 \mathrm{R}^{-/-}$ (C57BL/6 background, $\left.\mathrm{H} 2-\mathrm{K}^{\mathrm{b}}\right), \mathrm{LP} / \mathrm{J}\left(\mathrm{H} 2-\mathrm{K}^{\mathrm{bc}}\right), \mathrm{BALB} / \mathrm{c}$ $\left(\mathrm{H} 2-\mathrm{K}^{\mathrm{d}}\right), \mathrm{M} \mu \mathrm{MT}\left(\mathrm{H} 2-\mathrm{K}^{\mathrm{b}}\right)$, and NSG mice were purchased from the Jackson Laboratory (Bar Harbor, $\mathrm{ME})$. Littermate mice were interbred and housed in a pathogen-free environment at the animal facility of the Institute for Research in Immunology and Cancer. Animal protocols were approved by the Animal Care Committee of Université de Montréal.

\section{Antibodies, cytokines, reagents, and kits}

Recombinant IL-7 (\#217-17) and IL-21 (\#210-21 for mouse and \#200-21 for human) cytokines were purchased from PeproTech (Rocky Hill, NJ, USA). The flow cytometry antibodies CD3 (17A2), CD4 (GK1.5), CD5 (53-7.3), CD8 (53-6.7), NK1.1 (PK136), CD19 (1D3), CD25 (PC61), CD34 (RAM34), CD44 (1M7), CD45 (30-F11), CD62L (MEL-14), CD135 (A2F10.1), IL-10 (JES5-16E3), human CD3 (UCHT1), human CD4 (RPA-T4), human CD8 (SK1), human CD13 (WM15), human CD45 (H130), and Cytofix/Cytoperm Kits were purchased from BD Pharmingen (San Diego, CA, USA). FOXP3 (FJK-16S), granzyme B (NGZB), and human CD161 (HP-3G10) antibodies as well as monensin were purchased from eBioscence/Thermo Fisher (Waltham, MA, USA). Quantikines were purchased from R\&D Systems (Minneapolis, MN). CD3-CD28 beads, CellTrace $^{\mathrm{TM}}$, and TRIzol were purchased from Invitrogen (Burlington, ON, CA). Lipopolysaccharide (LPS), PMA, and ionomycin were purchased from 
Sigma (St. Louis, MO, USA). All cell isolation kits were purchased from STEMCELL Technologies (Vancouver, BC, Canada). RNA extraction kits were purchased from Qiagen (Toronto, ON, Canada).

\section{BMT and immune recovery assessment}

Irradiation of LP/J (11 Gy), IL-7 $7^{-/-}$(8.5 Gy), or BALB/c (8.5 Gy) recipient female was conducted prior to transplantation with $\mathrm{T}$ cell-depleted $5 \times 10^{6}$ RAG2p-GFPderived $\mathrm{BM}$ cells by intravenous injection. On the following day, mice were administered IL-21, IL-7 (both at $50 \mu \mathrm{g} / \mathrm{kg})$, or equivalent volume $(100 \mu \mathrm{l})$ of sterile PBS by intraperitoneal injections every 2 days over a period of 2 weeks (total of 6 injections). Immune reconstitution was assessed weekly using both the Scil vet $\mathrm{ABC}$ Plus $^{+}$hematological analyzer and flow cytometry on collected blood samples. BM, thymic, and spleen analyses were conducted as previously described [37].

\section{GVHD/GVT induction and analysis}

To induce GVHD, $\mathrm{T}$ cell-depleted BM derived from RAG2p-GFP or M MMT mice was supplemented with $10^{6}$ enriched $\mathrm{T}$ cells (from RAG2p-GFP), then used to transplant irradiated LP/J recipient animals followed by PBS/IL-21 treatments as previously described. For assessment of GVHD severity, mice were scored individually for five clinical parameters on a scale from 0 to 2 for weight loss, posture, activity, fur, and skin lesions. For GVT experiments, transplanted LP/J mice where challenged intravenously with $5 \times 10^{5}$ P815 tumor cells the day following BMT. Mice were sacrificed when weight loss reached $\geq 20 \%$ and/or the sum of total clinical scores was above 8 .

\section{Proliferation, cytokine measurements, and intracellular staining}

$\mathrm{T}$ cells were isolated from splenocyte suspension by negative selection and were stimulated with CD3-CD28 dynabeads. Cells or supernatants were collected $48 \mathrm{~h}$ post-stimulation for further analyses. For intracellular detection of cytokines, stimulated $\mathrm{T}$ cells were stained for $\mathrm{CD} 4 / \mathrm{CD} 8$ prior to intracellular staining according to the manufacturer's instructions. FOXP3 staining on $\mathrm{T}$ cells and IL-10 analysis in B cells were conducted as previously described [37, 38].

\section{Expression analysis of transcription factors}

$\mathrm{T}$ cells from spleens of transplanted mice were sorted in $900 \mu \mathrm{l}$ TRIzol ( $10^{6}$ cells per tube) followed by RNA extraction. Reverse transcription was performed by qPCR. Target gene values were normalized to endogenous control Gapdh.

\section{NSG transplantation using CB}

Cord blood (CB) units were obtained from the Ste-Justine blood bank (Montreal, Qc, Canada) following ethics approval. Mononucleated cells were first isolated by density centrifugation, then depleted from human $\mathrm{T}$ cells prior to their transplantation $\left(10^{5}\right.$ cells) in sublethally irradiated (3 Gy) NSG mice [39-41]. Transplanted NSG mice were then intraperitoneally injected with human IL-21 (50 or $100 \mu \mathrm{g} / \mathrm{kg})$ or human IL-7 $(50 \mu \mathrm{g} / \mathrm{kg})$ versus equivalent volumes of PBS $(100 \mu \mathrm{l})$ every 2 days over a period of 2 weeks (total of 6 injections). Peripheral blood was collected every 2 weeks and analyzed as described above. Transplanted mice were sacrificed at the end of the experiment to analyze their thymi and spleens.

\section{Statistical analyses}

$P$ values were calculated using the ANOVA and log-rank statistical test where applicable.

\section{Results}

IL-21 administration post-BMT correlates with accelerated lymphoid recovery

Amongst all immune subsets, $\mathrm{T}$ cells are the slowest to emerge (if any) post-BMT [8-10]. Following their development in the thymus, newly generated $\mathrm{CD} 4^{+}$ and $\mathrm{CD} 8^{+}$SP thymocytes, which are referred to as RTEs, egress to the periphery where they continue their maturation in secondary lymphoid organs [42]. To detect RTEs, peripheral blood samples are usually used to quantify TCR excision circle content, which represents a direct reflection of TCR rearrangements during intrathymic $\mathrm{T}$ cell development [43-45]. However, TCR excision circle quantification by PCR has several limitations and remains an indirect method that needs to be interpreted with caution [43-45]. Alternatively, RTEs and newly generated B cells both can be monitored using RAG2p-GFP mice, where GFP expression is controlled by the $\operatorname{Rag} 2$ promoter activity during $\mathrm{T}$ and $\mathrm{B}$ lymphopoiesis [37, 46, 47]. Therefore, we first quantified the physiological ranges of total $\mathrm{GFP}^{+}$(RTEs and newly developed B cells), $\mathrm{GFP}^{+} \mathrm{CD} 19^{+}$(newly developed $\mathrm{B}$ cells), or $\mathrm{GFP}^{+} \mathrm{CD}^{+}$ (RTEs) cells in circulation using blood samples collected from unirradiated control RAG2p-GFP mice prior to conducting BMT experiments (Fig. 1a). According to these ranges (displayed as pink-shaded areas), IL-21 administration to LP/J mice accelerated significantly lymphoid recovery in contrast to PBSor IL-7-treated mice (Fig. 1b). In particular, GFP ${ }^{+} \mathrm{CD} 19^{+}$cells (Fig. 1c) reached physiological levels 3 weeks post-BMT whereas $\mathrm{GFP}^{+} \mathrm{CD}^{+}$levels (Fig. 1d) were normalized by the 5 th week (indicated by red arrows) following transplantation. Upon further dissection, enhanced re-establishment of peripheral 
a

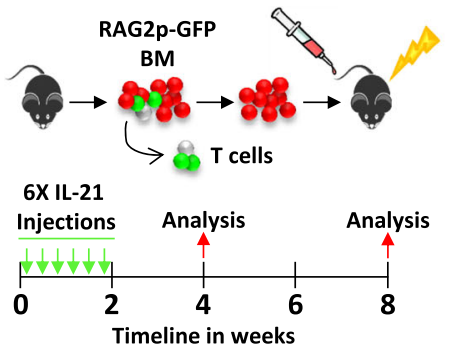

b
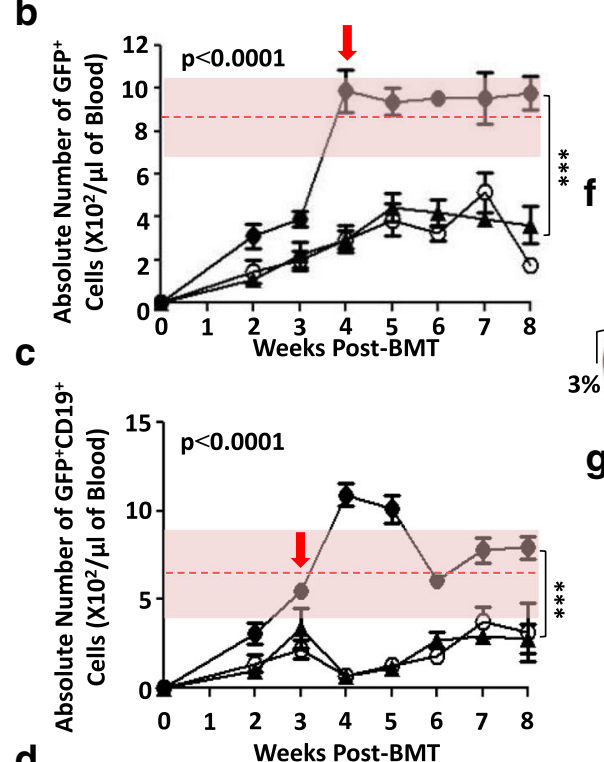

d

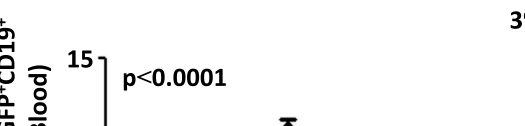

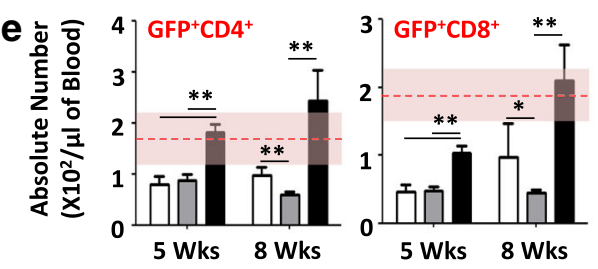
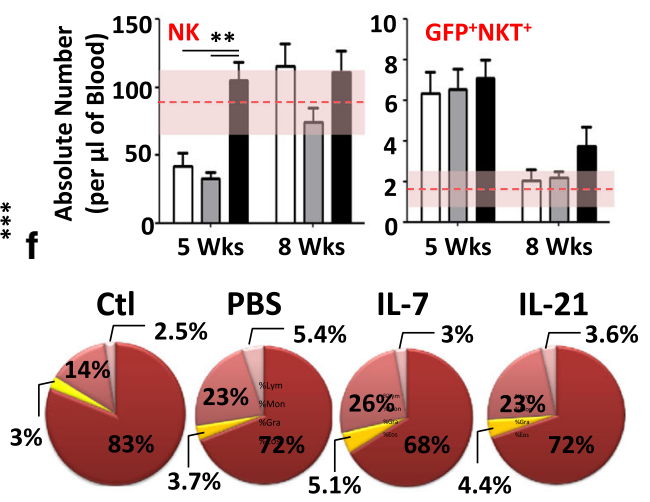

g

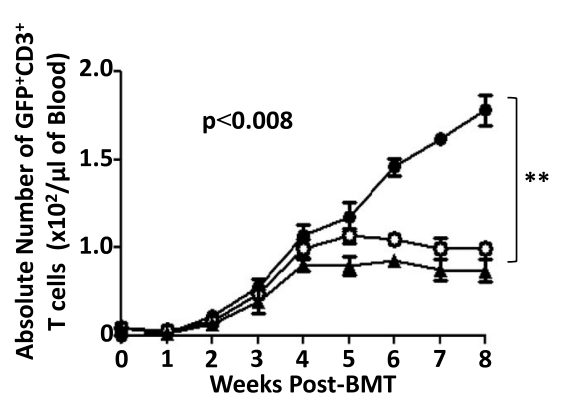

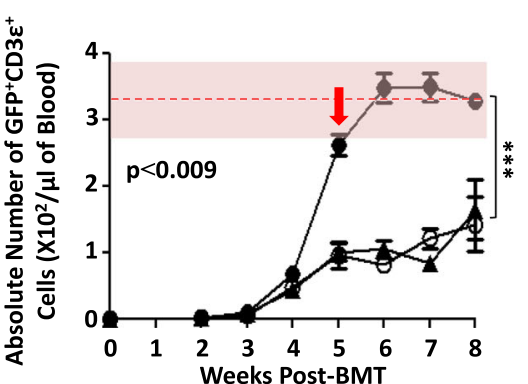

Fig. 1 Peripheral T cell reconstitution. a Schematic cartoon summarizing the BMT protocol. Absolute counts of GFP ${ }^{+}$(b), GFP ${ }^{+}$CD19 ${ }^{+}$(c), or GFP ${ }^{+} \mathrm{CD}^{+}(\mathbf{d})$ T cells in peripheral blood of transplanted mice ( $\left.n=10 / \mathrm{group}\right)$. The red dashed line within the pink-shaded area represents the mean physiological level of the GFP ${ }^{+}$population of interest being analyzed +1 standard deviation calculated using blood samples collected from 10 unirradiated RAG2p-GFP mice. The treatment groups are represented as follows: PBS (empty circle), IL-7 (filled triangle), and IL-21 (filled circle). e Absolute counts of $\mathrm{GFP}^{+} \mathrm{CD}^{+}, \mathrm{GFP}^{+} \mathrm{CD}^{+}, \mathrm{NK}^{+}$, or $\mathrm{GFP}^{+} \mathrm{NKT}^{+}$cells at 5 and 8 weeks post-BMT ( $n=10 / \mathrm{group}$ ). The PBS group is represented by white bars, IL-7 by gray bars, and IL-21 by black bars. $\mathbf{f}$ Pie charts reflecting the percentages of all major blood-circulating immune populations. The represented groups are follows: lymphocytes in dark red (68-83\%), granulocytes in pink (14-26\%), monocytes in yellow (3-5.1\%), and eosinophils in light pink (2.5-5.5\%). Control mice (Ct/) represent unirradiated mice. $\mathbf{g}$ A representative BMT experiment conducted in IL-7 ${ }^{-/-}$ (on a C57BL/6 background) recipient mice ( $n=10 /$ group). The treatment groups are represented as follows: PBS for RAG2p-GFP-derived $\mathrm{BM} \rightarrow \mathrm{IL}-7^{-/-}$(empty circle), IL-21 (50 $\left.\mathrm{gg} / \mathrm{kg}\right)$ for RAG2p-GFP-derived BM $\rightarrow \mid \mathrm{L}-7^{-/-}$(filled triangle), and a technical control consisting of PBS administration to RAG2p-GFP-derived BM $\rightarrow W T$ C57BL/6 setting (filled circle). All experiments were conducted at least three times with * $P<0.05$, ${ }^{* *} P<0.01$, and ${ }^{* * *} P<0.0001$

$\mathrm{GFP}^{+} \mathrm{CD}^{+}, \mathrm{GFP}^{+} \mathrm{CD}^{+}, \mathrm{GFP}^{+} \mathrm{NKT}^{+}$, and $\mathrm{NK}^{+}$cells were observed at both 5th and 8th weeks post-BMT in IL-21-treated mice (Fig. 1e) with no overrepresentation of myeloid versus lymphoid cells in any of the transplanted groups (Fig. 1f).
Given the profound effect of IL-21 on T cell recovery post-BMT, we next examined whether it displays redundant function with IL-7, the major thymopoietin known to support $\mathrm{T}$ cell development [48]. To test this hypothesis, peripheral $\mathrm{GFP}^{+} \mathrm{CD}^{+} \mathrm{T}$ cells were quantified 
in $\mathrm{IL}_{-} 7^{-/-}$recipient mice transplanted with $\mathrm{T}$ celldepleted RAG2p-GFP BM. Although no differences in the generation of $\mathrm{GFP}^{+} \mathrm{CD}^{+} \mathrm{T}$ cells were depicted between PBS- and IL-21-treated IL- $7^{-/-}$recipient animals, the overall RTE levels were significantly lower compared to WT C57BL/6 recipient mice on the PBS regimen (Fig. 1g). These results clearly indicate that IL-21 can indeed accelerate $\mathrm{T}$ cell recovery but requires endogenous IL-7 signaling to exert its effects.

\section{IL-21 triggers the expansion of BM progenitors}

The thymus lacks self-renewing stem cells $[49,50]$. Its function relies therefore on sustained seeding by BMderived progenitors $[49,50]$. Although the nature/ phenotype of the thymus-settling population(s) remains a matter of debate, BM progenitors are still considered as the limiting substrate for immune reconstitution post-BMT [49-58]. To determine whether the improved peripheral $\mathrm{T}$ cell reconstitution previously observed in LP/J recipient mice was due to a direct effect mediated by IL-21 on the BM compartment, hematopoietic stem cells (HSCs) were analyzed in recipient mice 4 weeks following transplantation using well-defined cell surface markers [59]. Aside from the significant increase in total BM cell number (Fig. 2a), $\mathrm{Lin}^{-} \mathrm{Sca}^{+}{ }^{+}$-kit ${ }^{+}$(LSK) counts in IL-21-treated animals were highly comparable to those in unirradiated control mice (Fig. 2b). This observed increase in LSKs was not due to long-term (LT)-HSC expansion (Fig. 2c), but rather to augmented numbers of short-term (ST)-HSCs (Fig. 2d) and multipotent progenitors (MPPs) (Fig. 2e). In fact, the effect of IL-21 on LSKs is not surprising as these BM subsets express the IL-21R (Fig. 2f). To further support our in vivo observations, we supplemented freshly plated BM cells with ascending doses of IL-21 (0-1000 ng/ml) and noticed a dose-depending increase in LSK frequency with an optimal effect reached at $25-50 \mathrm{ng} / \mathrm{ml}$ (Fig. $2 \mathrm{~g}, \mathrm{~h}$ ). Further validations by intracellular Ki-67 staining conducted on WT- versus $\mathrm{IL}-21 \mathrm{R}^{-1-}$-derived BM treated with $\mathrm{IL}-21(50 \mathrm{ng} / \mathrm{ml})$ revealed a twofold increase in LSK expansion over basal levels (Additional file 1: Figure S1; Fig. 2i, j). The sum of these results clearly links accelerated lymphoid recovery mediated by IL-21 to the proliferation of BMresident ST-HSCs and MPPs, which represent the hub of thymus-settling progenitors $[49,51-55]$.

\section{Thymopoiesis stimulation by IL-21 re-establishes a peripheral naïve $\mathrm{T}$ cell pool}

The enhanced recovery of ST-HSCs and MPPs postBMT is indicative of improved engraftment and certainly accounts for the increased peripheral $\mathrm{T}$ cell development observed in IL-21-treated animals [60-62]. However, IL$21 \mathrm{R}$ was also reported to be expressed on thymic progenitors at the DN and DP stages [35, 36]. This suggests that IL-21 can directly mediate thymocyte proliferation in situ. To confirm this assumption, thymic tissues were resected from transplanted mice 4 weeks post-BMT and analyzed for both the hematopoietic $\left(\mathrm{CD} 45^{+}\right)$and non-hematopoietic $\left(\mathrm{CD} 45^{-}\right)$compartments (Fig. 3a). Interestingly, thymi derived from the IL-21-treated group were comparable in size to those from unirradiated control mice as opposed to PBS-treated animals, which remained atrophied (Fig. 3b). Thymocyte analysis by flow cytometry clearly shows normal GFP frequency levels in IL-21-treated animals (Fig. 3c) with full recovery of both total and $\mathrm{GFP}^{+}$thymocytes (Fig. 3d). All major thymic subsets (Fig. 3e) including early thymic progenitors (ETPs; in $^{-} \mathrm{CD} 8 \alpha^{-} \mathrm{CD} 25^{-} \mathrm{c}-\mathrm{kit}^{+}$), DN2 (lin ${ }^{-} \mathrm{CD} 44^{-} \mathrm{CD} 8^{-} \mathrm{CD} 25^{+} \mathrm{CD} 44^{+}$), and DN3 $\left(\mathrm{lin}^{-} \mathrm{CD} 4^{-} \mathrm{CD} 8\right.$ ${ }^{-} \mathrm{CD} 25^{+} \mathrm{CD} 44^{-}$) thymocytes (Fig. 3f) recovered in response to IL-21 treatment. Finally, analysis of enzymatically digested thymic tissues revealed significant improvement in total $\left(\mathrm{CD} 45^{-} \mathrm{EpCam}^{+}\right)$, cortical $\left(\mathrm{CD}_{4} 5^{-} \mathrm{EpCam}^{+} \mathrm{UEA1}^{-} \mathrm{Ly}_{51}{ }^{+}\right.$), and medullary (CD45 ${ }^{-} \mathrm{EpCam}{ }^{+} \mathrm{UEA1}{ }^{+} \mathrm{Ly} 51^{-}$) thymic epithelial cells (TECs) in the IL-21-treated group when compared to PBS control mice (Fig. 3g).

The observed $\mathrm{T}$ cell development triggered by IL-21 is expected to qualitatively change the content of secondary lymphoid organs due to enhanced RTE output (Fig. 1d, e). Although all spleens derived from $\mathrm{LP} / \mathrm{J}$ transplanted animals looked similar in size to those from unirradiated control mice (Fig. 4a), higher GFP frequency (Fig. 4b) and counts of total as well as $\mathrm{GFP}^{+}$splenocytes were detected in the IL-21 group (Fig. 4c). Not only did IL-21 administration culminate in full reconstitution of $\mathrm{CD} 4^{+}, \mathrm{CD}^{+}$, and $\mathrm{CD} 19^{+}$cells (Fig. 4d), but the majority of developed $\mathrm{CD}^{+}$and $\mathrm{CD}^{+} \mathrm{T}$ cells displayed a naïve phenotype $\left(\mathrm{CD} 62 \mathrm{~L}^{\mathrm{hi}} \mathrm{C}\right.$ $\mathrm{D} 44^{\mathrm{lo}}$ ) (Fig. 4e) with a normal TCRv $\beta$ distribution (Fig. 4f). To determine whether IL-21 administration to transplanted mice affects the nature of newly developed $\mathrm{T}$ lymphocytes, we next examined their functionality in response to TCR stimulation. No significant changes could be detected in their proliferative capacity (Additional file 1: Figure S2A) or ability to secrete a wide range of cytokines (Additional file 1: Figure $\mathrm{S} 2 \mathrm{~B}$ ). Furthermore, all stimulated $\mathrm{T}$ cells expressed similar levels of granzyme B (Additional file 1: Figure S2C, D) with no depicted differences in their expression of Bcl6, Nfat, T-bet, Gata3, Roryt, and Foxp3 transcripts (Additional file 1: Figure S3). Together, our results suggest that IL-21 administration post-BMT stimulates thymopoiesis efficiently consequently triggering the emergence of peripheral naïve $\mathrm{T}$ cell pool displaying normal functionality. 


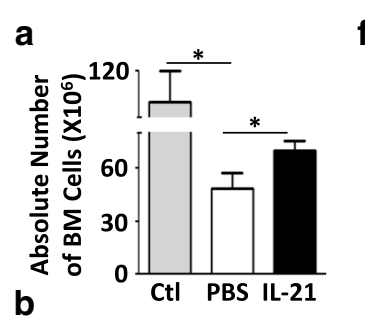

f

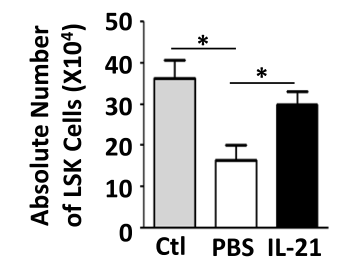

C

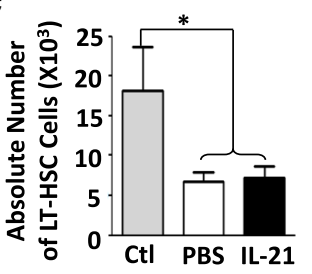

d

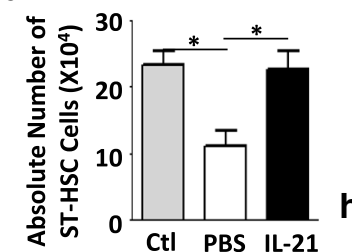

e

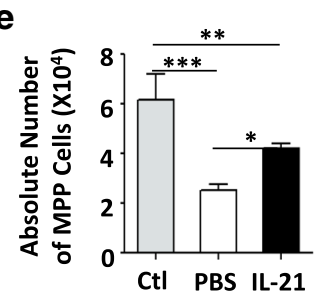

g
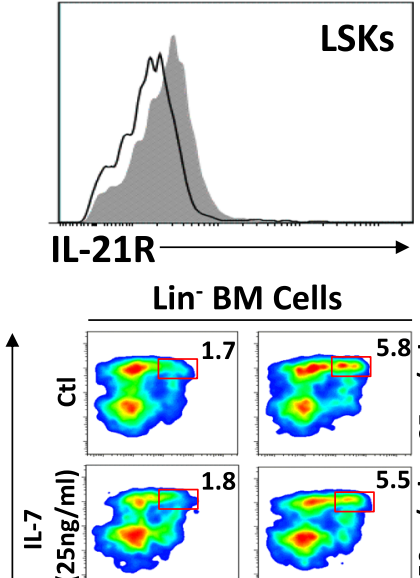

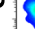
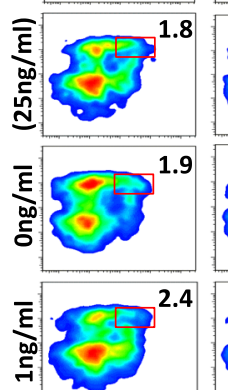

2.4
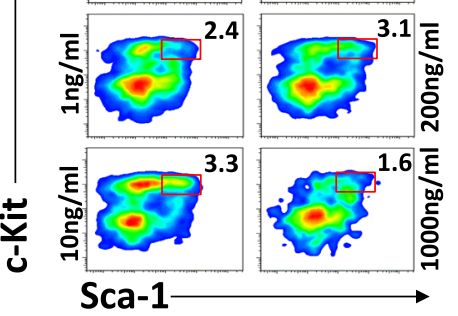

,

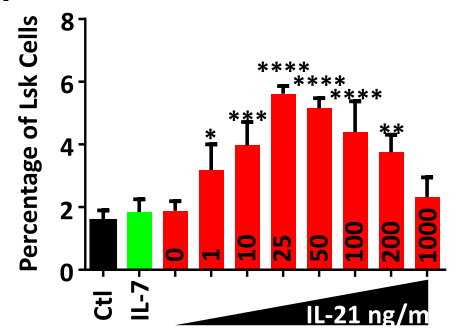

i $\quad$ Lin- Sca1 $^{+}$ckit $^{+}$

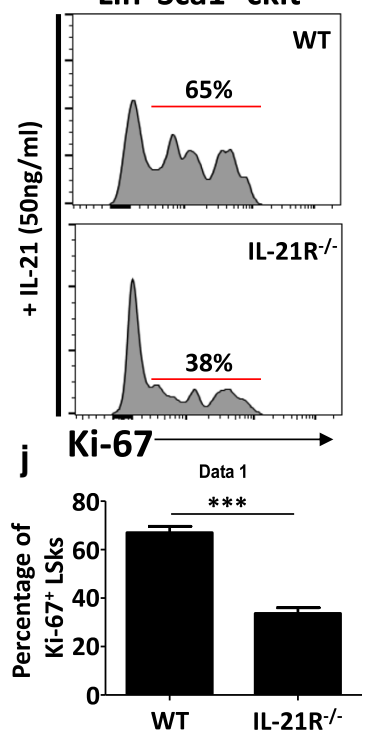

Fig. 2 BM engraftment. Absolute counts of a total BM cells, b LSKs, $\mathbf{c}$ LT-HSCs, $\mathbf{d}$ ST-HSCs, and e MPPs. Unirradiated mice were used as controls. f Representative flow cytometry analysis of IL-21R expression on the surface of LSKs. Isotype control is shown in black line whereas IL-21R staining is shown in filled gray histogram. $\mathbf{g}$ Representative flow cytometry experiment analyzing the frequency of LSKs in response to ascending doses of IL-21 (0-1000 ng/ml). Equivalent volume of PBS or IL-7 at $25 \mathrm{ng} / \mathrm{ml}$ was used as controls. $\mathbf{h}$ Quantification of LSK frequency derived from the experiment shown in $\mathbf{g}$ i Representative intracellular Ki-67 staining in WT versus IL-21 $\mathrm{R}^{-/-}$LSK $48 \mathrm{~h}$ post-treatment with $50 \mathrm{ng} / \mathrm{ml}$ of IL-21. j Quantification of $\mathrm{KI}^{-67^{+}} \mathrm{LSKs}$ derived from the experiment shown in i. All experiments were conducted at least three times with $* P<0.05$, ${ }^{* *} P<0.01$, ${ }^{* *} P<0.0001$, and ${ }^{* * * *} P<0.00001$

\section{IL-21 drives regulatory B10 cell expansion in transplanted} animals

IL-21 can exert actions on multiple lymphoid and myeloid populations with a potential role in the modulation/ development of immune regulatory cells [63]. For instance, IL-21 ${ }^{-/-}$mice display high numbers of FOXP3expressing Tregs, suggesting a function for IL-21 in blocking Treg development [28]. Elegant mechanistic studies further demonstrated that IL-21 impedes Treg generation and viability in vitro by inhibiting IL-2 production [64]. Besides Tregs, IL-21 supports B cell development in the BM, suggesting a possible parallel effect on regulatory B cells (B10) [38]. In support of this notion, activation and proliferation of B10 cells were reported to be dependent on both cognate interactions with $\mathrm{CD}^{+} \mathrm{T}$ cells and IL-21 during an inflammatory process [38]. Based on all these facts, we next scrutinized whether IL-21 administration affects the development of Tregs in mice undergoing de novo hematopoiesis and found a significant but trivial increase in $\mathrm{CD}^{+} \mathrm{CD}_{25} 5^{+} \mathrm{FOXP3}^{+} \mathrm{T}$ cell number (Fig. 4g). However, the same IL-21 group displayed a pronounced 

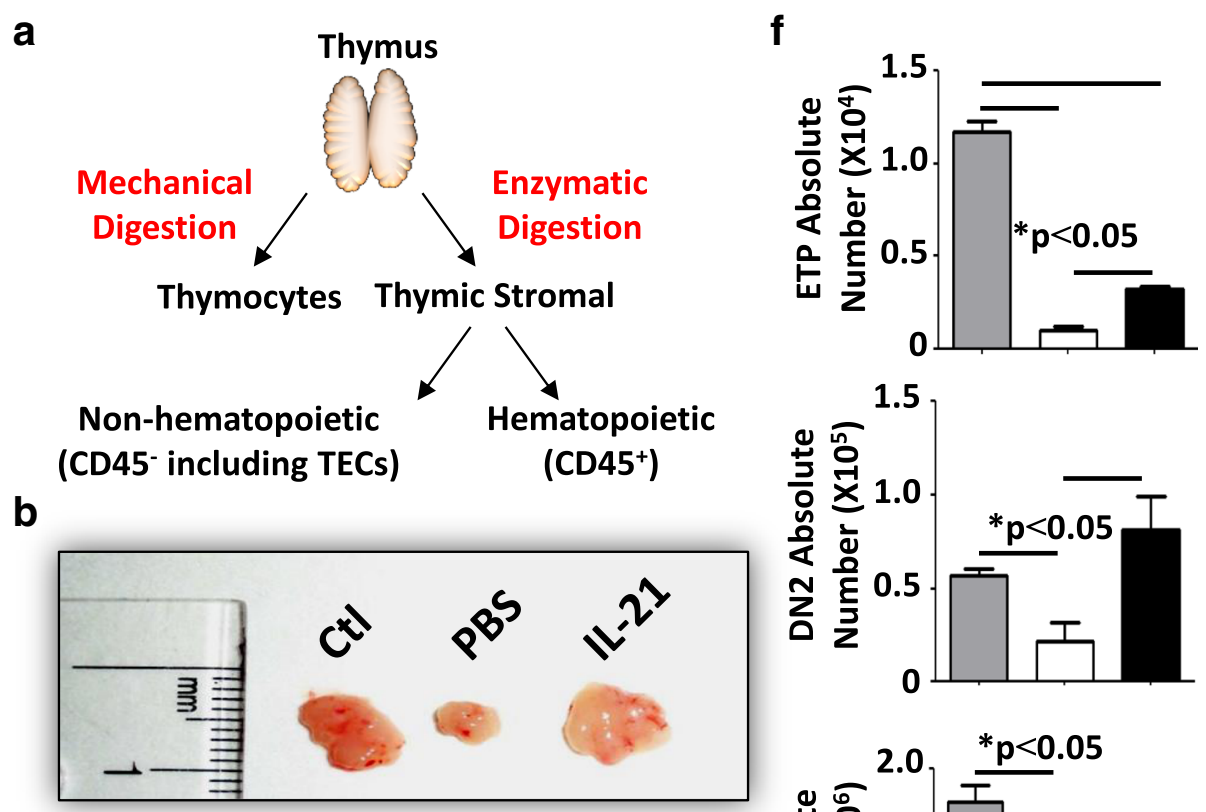

C
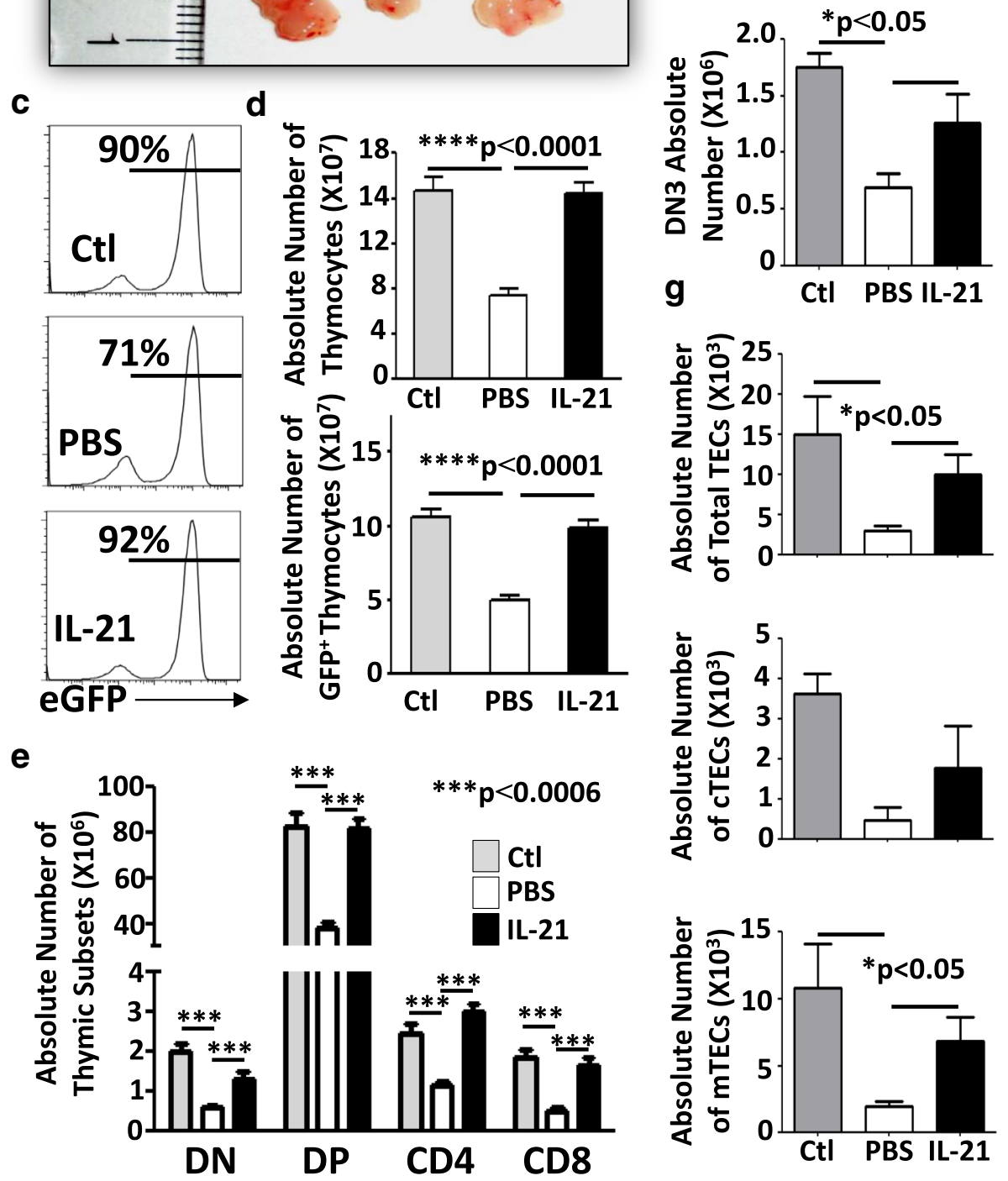

Fig. 3 (See legend on next page.) 
(See figure on previous page.)

Fig. 3 Analysis of thymic tissues. a Schematic diagram displaying the approach used for thymic analysis. $\mathbf{b}$ A representative photograph of thymi derived from treated mice. c Representative flow cytometry assessing the GFP frequency of treated vs. ctl mice. $\mathbf{d}$ Absolute numbers of total (top) or GFP (bottom) thymocytes. e Absolute counts of all thymic subsets. f Absolute counts of ETP (top panel), DN2 (middle panel), and DN3 (bottom panel) thymocytes. g Absolute counts of total (top panel), cortical (middle panel), and medullary (bottom panel) TECs. All shown experiments were conducted at least three times with ${ }^{*} P<0.05$ and ${ }^{* *} P<0.0001$ and $n=10 /$ group

a

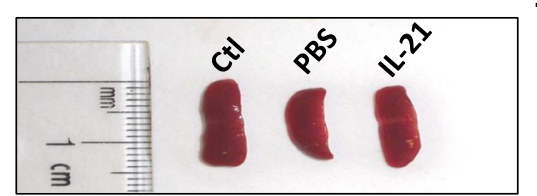

b

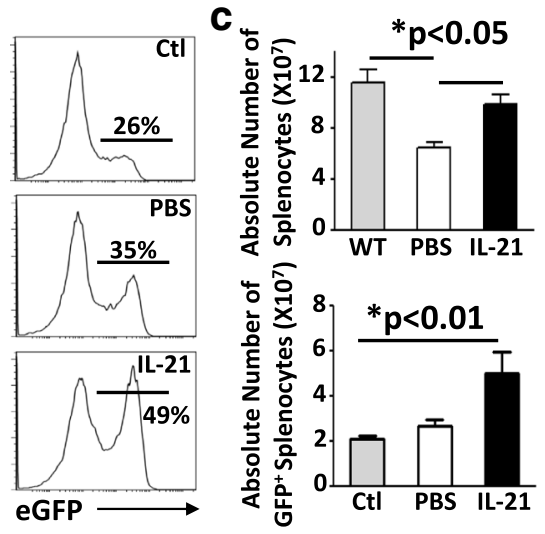

d

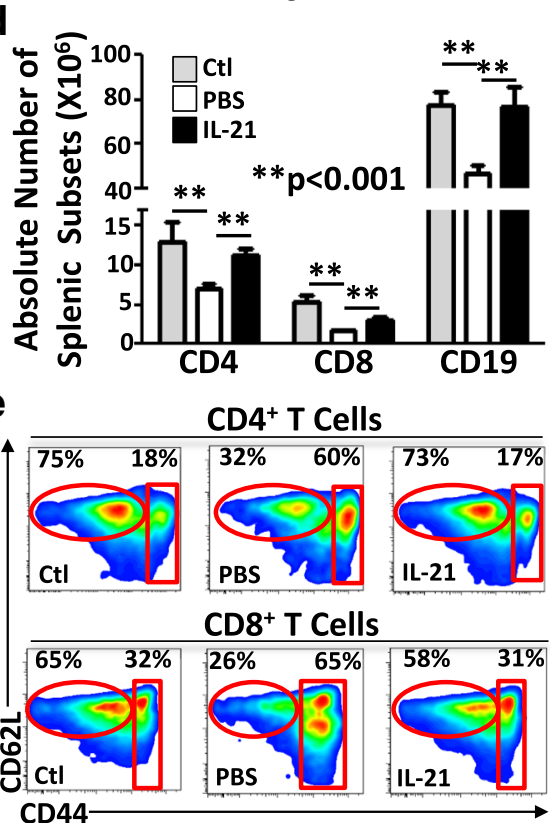

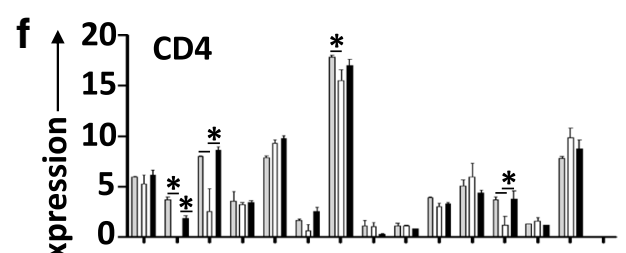

齐 0

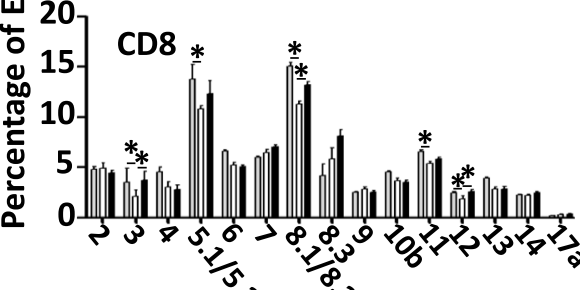

VB Chains:
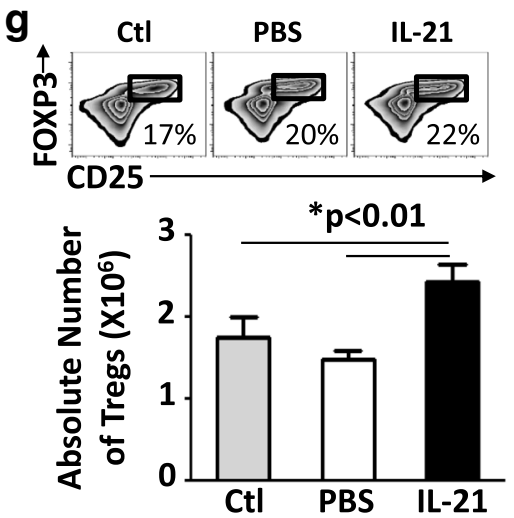

h

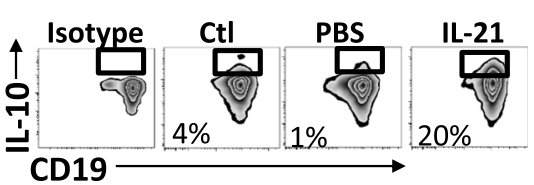

ฆे

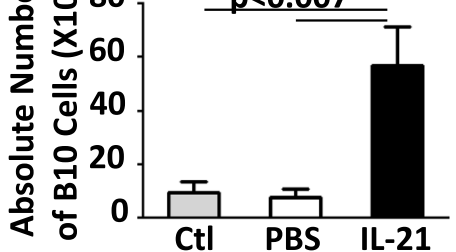

Fig. 4 Spleen analysis. a A representative photograph of spleens derived from treated mice. b Representative flow cytometry of GFP expression profile in splenocytes. c Absolute counts of total (top panel) or GFP (bottom panel) splenocytes. $\mathbf{d}$ Absolute counts of all splenic subsets. e Representative flow cytometry analysis of naïve $\left(\mathrm{CD} 62 \mathrm{~L}^{+} \mathrm{CD} 44^{-}\right)$and effector/memory $\left(\mathrm{CD} 62 \mathrm{~L}^{+} \mathrm{CD} 44^{+}\right) \mathrm{CD} 4^{+}$and $\mathrm{CD} 8^{+} \mathrm{T}$ cells. $\mathbf{f} \mathrm{TCRv} \beta$ distribution assessed by flow cytometry. $\mathbf{g}$ Analysis of the frequency (top panel) and absolute count of Tregs. $\mathbf{h}$ Analysis of the frequency (top panel) and absolute count of IL-10-producing regulatory CD $1 d^{\text {hi }} \mathrm{CD}^{+}$B cells. Isotype staining was used as a negative control for IL-10 detection in comparison to ctl (non-transplanted WT C57BL/6 mice), PBS-treated, or IL-21-treated LP/J mice. All shown experiments were conducted at least three times with ${ }^{*} P<0.05$ and ${ }^{* *} P<0.001$ and $n=10 /$ group 
increase in regulatory $\mathrm{B}$ cells based on the quantification of IL-10-competent $\mathrm{CD} 1 \mathrm{~d}^{\text {hi }} \mathrm{CD}^{+} \mathrm{B}$ cells (20\% as opposed to $1-4 \%$ in control PBS-treated animals-Additional file 1: Figure S4; Fig. 4h). Therefore, IL-21 administration post-BMT enhances significantly the level of regulatory B10 cells along with a limited effect on Treg development.

\section{IL-21 protects transplanted mice from GVHD while preserving the GVT effect}

So far, all BMT experiments were conducted using $\mathrm{T}$ cell-depleted BM to assess the thymus-boosting properties of IL-21 in the absence of GVHD-induced damages. To evaluate the effect of IL-21 on GVHD, we next supplemented the BM graft with mature RAG2p-GFPderived allogeneic $\mathrm{T}$ cells (donor lymphocyte infusion (DLI)) and found that PBS-treated animals became ill as of the 3rd week post-BMT with a 50\% survival rate (Fig. 5a) according to weight loss assessment (Fig. 5b). In sharp contrast, none of the IL-21-treated animals developed GVHD signs (Fig. 5a, b). As the proportion of regulatory B cells was enhanced in IL-21-treated animals (Fig. 4h), we next addressed whether these Bregs were behind the GVHD protection observed in transplanted $\mathrm{LP} / \mathrm{J}$ mice. To test this hypothesis, $\mathrm{T}$ cell-depleted BM derived from $\mathrm{M} \mu \mathrm{MT}$ mice (deficient in B cell development) was supplemented with mature $\mathrm{T}$ cells from RAG2p-GFP mice, then transplanted into $\mathrm{LP} / \mathrm{J}$ animals followed by PBS or IL-21 treatments. Interestingly, 40\% survival was obtained in the IL-21-treated group whereas all PBS control mice died by the 3rd week postBMT (Fig. 5c, d). As these observations clearly indicate a role for Bregs in mediating GVHD protection, we next tested whether IL-21-enhanced Breg development would lead to similar outcome in a complete MHC-mismatch $\mathrm{BMT}$ model $(\mathrm{C} 57 \mathrm{BL} / 6 \rightarrow \mathrm{BALB} / \mathrm{c})$. Under this context, all $\mathrm{BALB} / \mathrm{c}$ transplanted mice died within the 3rd week post-BMT with no observed differences between PBS and IL-21 groups (Fig. 5e).

GVHD induction is usually concomitant with GVT [65]. We therefore corroborated impaired GVT effect in IL-21-treated animals due to the absence of GVHD signs. To validate this hypothesis, $\mathrm{LP} / \mathrm{J}$ recipient mice were transplanted with RAG2p-GFP-derived BM with or without DLI followed by a challenge the following day using the mastocytoma cell line P815 (DBA/2-derived). As predicted, all PBS-treated mice transplanted with $\mathrm{T}$ cell-depleted BM died around the 4th week (Fig. 5f; green line) whereas DLI led to $60 \%$ survival up to 12 weeks post-BMT (Fig. 5f; blue line). Surprisingly, 90\% of challenged IL-21-treated mice transplanted with $\mathrm{T}$ cell-depleted BM survived (Fig. 5f; black line), whereas complete protection was obtained if animals underwent DLI (Fig. 5f; red line). It should be noted however that
IL-21 can trigger apoptosis of IL-21R-expressing lymphomas $[66,67]$. To confirm that the observed GVT effect is solely dependent on the anti-tumoral effect mediated by the newly developed thymus-selected $\mathrm{T}$ cells as opposed to a direct apoptosis-inducing effect mediated by IL-21 itself, we assessed the expression of the IL-21R $\alpha$ chain on P815 by flow cytometry and found that it was indeed negative (Fig. 5f; histogram figure). We concluded therefore that IL-21 can bypass GVHD induction, at least in the MHC-matched allogeneic graft setting, while retaining beneficial GVT effects mediated by the newly generated $\mathrm{T}$ cells.

\section{IL-21 triggers T cell development in humanized mice}

To test whether human IL-21 displays a thymopoiesisstimulating effect akin to its murine ortholog, we next transplanted immunodeficient NSG mice with T celldepleted CB units. Two doses of human IL-21 were tested (50 and $100 \mu \mathrm{g} / \mathrm{kg})$ versus IL-7 $(50 \mu \mathrm{g} / \mathrm{kg})$ or equal volume of PBS following the same injection schedule previously used for LP/J mice. Peripheral blood analysis over 16 weeks revealed a significant increase in both human $\mathrm{CD}_{4} 5^{+}$and $\mathrm{CD}^{+}$cells (Fig. 6a) only in the group receiving IL-21 at a dose of $50 \mu \mathrm{g} / \mathrm{kg}$. The same IL-21-treated NSG group displayed 90\% chimerism with over $30 \%$ circulating human $\mathrm{CD}^{+} \mathrm{T}$ cells (Fig. 6b). Besides the absence of a beneficial effect for IL-7, the high IL-21 dose $(100 \mu \mathrm{g} / \mathrm{kg})$ failed at improving human $\mathrm{CD}^{+}$ $\mathrm{T}$ cell development (Fig. 6a), which could be explained by a blockade at the DN stage in the thymi of NSG transplanted mice (Fig. 6c). Detailed thymic analysis of the $50 \mu \mathrm{g} / \mathrm{kg}$ group showed pronounced human thymocyte counts (total and human $\mathrm{CD} 45^{+}$cells) with increased levels of DN, DP, and SP thymocytes (Fig. 6d). Their spleens contained higher counts of total and human $\mathrm{CD} 45^{+}$cells as well as significantly increased levels of $\mathrm{CD}^{+}, \mathrm{CD}^{+}, \mathrm{CD}^{+}$, and $\mathrm{CD} 19^{+}$SP lymphocytes with no apparent differences in $\mathrm{CD}^{+} 3^{+}$(granulocytes) or $\mathrm{CD}_{161}{ }^{+}(\mathrm{NK} / \mathrm{NKT})$ counts (Fig. 6e). Altogether, these observations clearly indicate that human IL-21 is equivalent to its murine ortholog in stimulating the development of $\mathrm{MHC}$-restricted human $\mathrm{CD}^{+} \mathrm{T}$ cells in immunodeficient NSG mice.

\section{Discussion}

The thymus is a specialized microenvironment dedicated to the generation of self-tolerant $\mathrm{T}$ cells with a broad TCR repertoire [68-70]. This is vital to ensure the development of adaptive immune responses without leading to autoimmune diseases. The importance of the thymus, however, must be reconciled with the fact that it is exquisitely sensitive to a range of external insults including those derived from the conditioning regimen used prior to $\mathrm{BMT}[71,72]$. Although pediatric patients can recover 


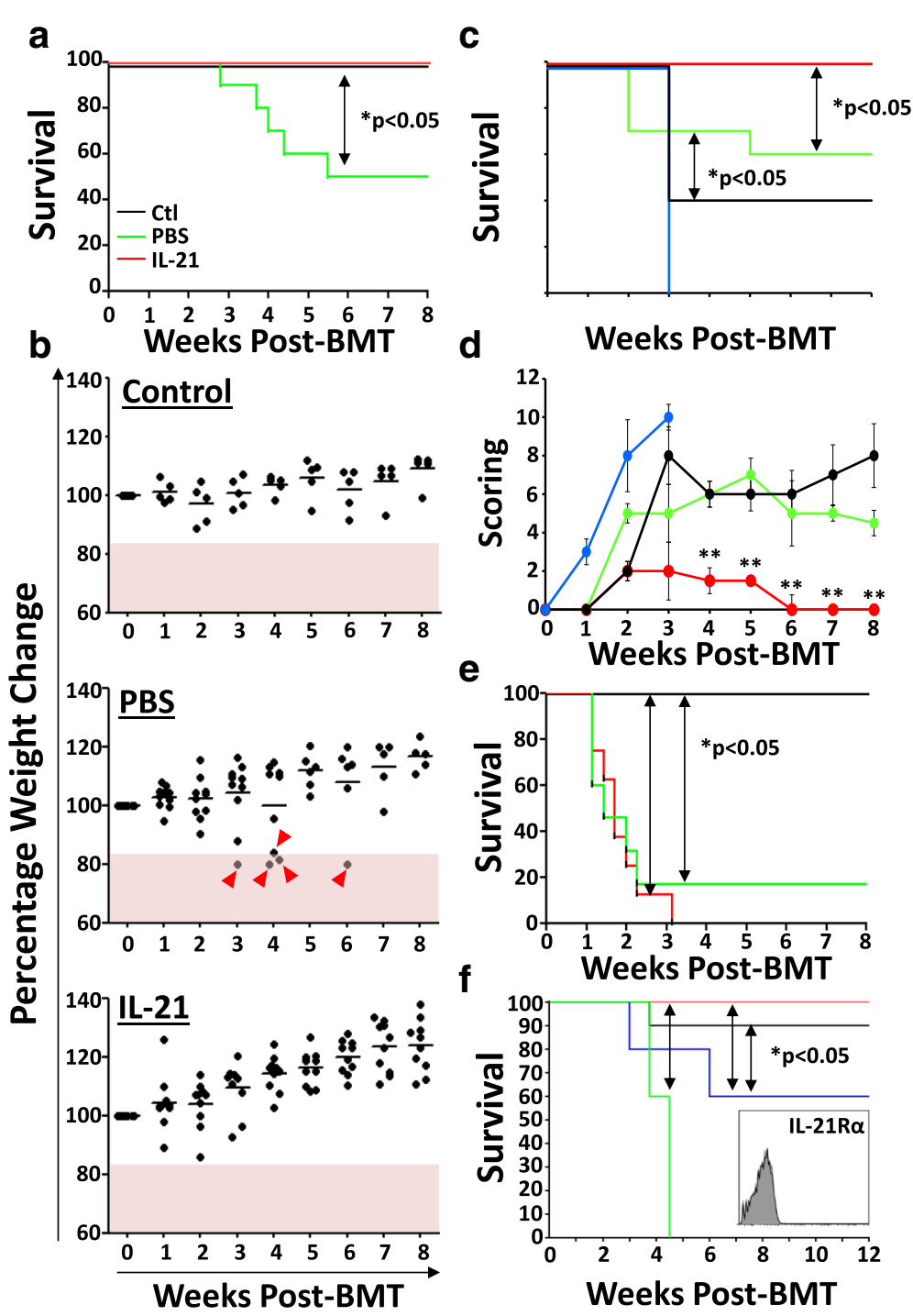

Fig. 5 Effect of IL-21 on GVHD and GVT. a Survival curve following MHC-matched allogeneic BMT (C57BL/6 $\rightarrow$ LP/J) depicting control (syngeneic transplantation) in black, PBS-treated allogeneic BMT in green, and IL-21-treated allogeneic BMT in red. $\mathbf{b}$ Weight loss analysis of transplanted animals over 8 weeks post-BMT. Pink area represents a loss of $\geq 20 \%$. Lost mice are indicated by red arrowheads. c Survival curve following MHCmatched allogeneic BMT depicting PBS-treated allogeneic BMT (WT C57BL/6 $\rightarrow$ LP/J) in green, IL-21-treated allogeneic BMT (WT C57BL/6 $\rightarrow$ LP/J)

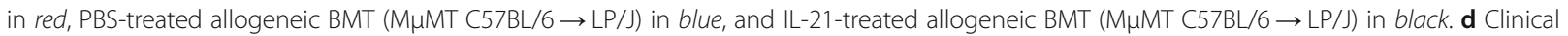
score evaluation for the experiment shown in c. e Survival curve following complete MHC-mismatch allogeneic BMT (C57BL/6 $\rightarrow$ BALB/c). The color code for the groups is exactly the same one shown in a. f Survival curve for the GVT experiment conducted by challenging transplanted mice with P815 mastocytoma tumor cells. The color code for each group is as follows: green for BMT + PBS, black for BMT + IL-21, blue for BMT + $\mathrm{DLI}+\mathrm{PBS}$, and red for BMT + DLI + IL-21. e Representative flow cytometry analysis of IL-21Ra expression on the surface of the P815 tumor cell line. All shown experiments were conducted at least three times with ${ }^{*} P<0.05$ and $n=10 /$ group

their thymic function post-transplantation, the latter remains blunted in aged individuals leading consequently to diverse clinical complications [6]. This explains why accelerated $\mathrm{T}$ cell recovery correlates with improved survival post-BMT $[11-13,16,20,24]$. For de novo generation of thymus-derived naïve $\mathrm{T}$ cells to occur, three conditions must be fulfilled following BMT: (i) efficient HSC engraftment, (ii) active thymic seeding by BMderived progenitor cells, and (iii) a thymic architecture conducive to progenitor migration/differentiation. Using a series of BMT experiments, we have shown that IL-21 administration to transplanted mice enhances de novo thymopoiesis by targeting both primary lymphoid tissues: the BM and the thymus (Fig. 7). More specifically, IL-21 promotes the expansion of ST-HSCs and MPPs within the BM-resident LSK population, which represents the source of building blocks required for rapid immune recovery [49, 51-55]. Although not directly 

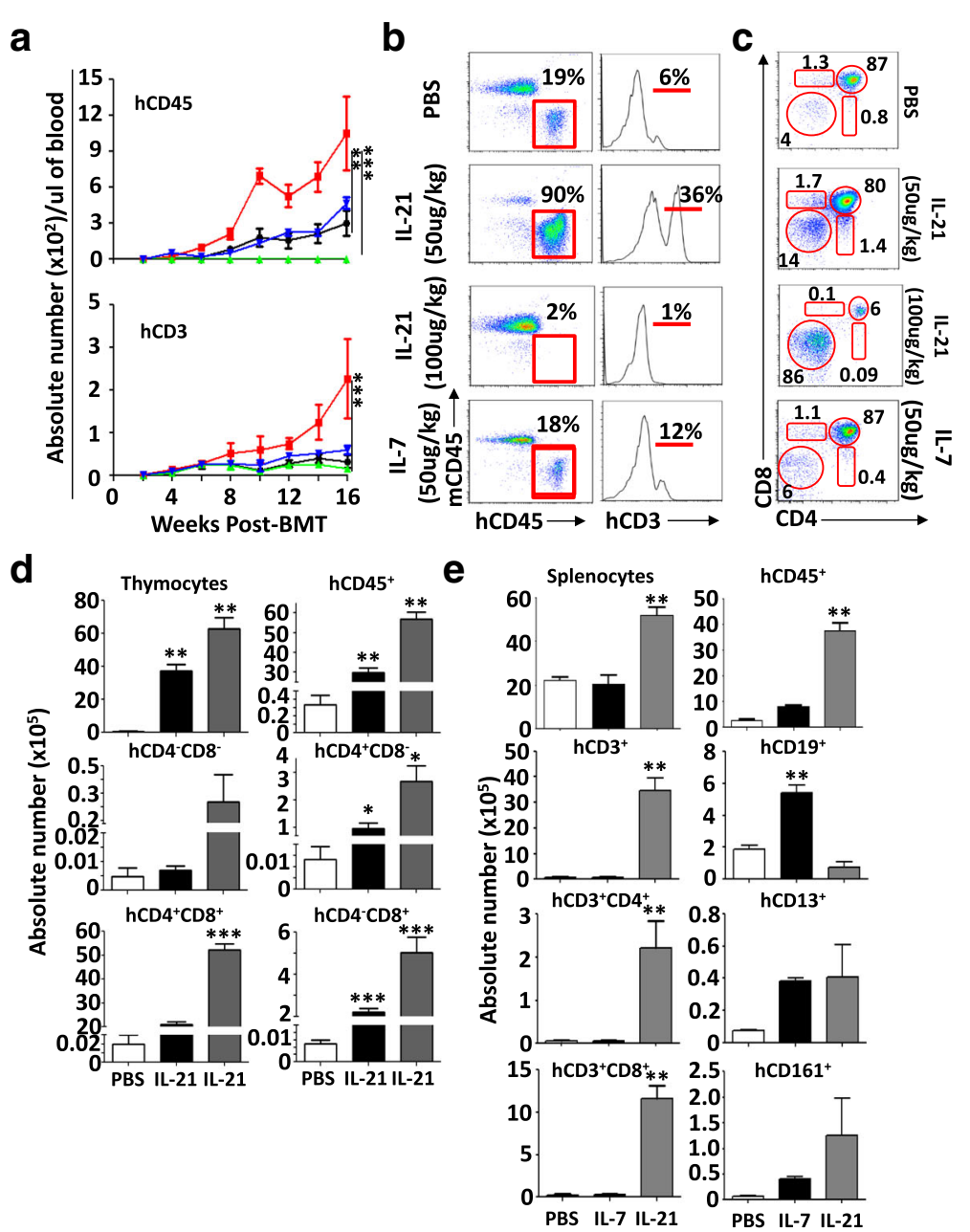

Fig. 6 Human T cell development in NSG mice. a Peripheral blood analysis for the development of CD45 $5^{+}$and $\mathrm{CD}^{+}$human cells in NSG mice transplanted with T cell-depleted CB. The PBS group is shown in black, the IL-7 group at $50 \mu \mathrm{g} / \mathrm{kg}$ is shown in blue, the IL-21 group at $50 \mu \mathrm{g} / \mathrm{kg}$ is shown in red, and the IL-21 group at $100 \mu \mathrm{g} / \mathrm{kg}$ is shown in green. $\mathbf{b}$ Representative flow cytometry assessment of murine vs. human CD45 cells (left panels) or human $\mathrm{CD}^{+} \mathrm{T}$ cells (right panels) in peripheral blood of NSG mice 16 weeks post-transplantation. c Representative flow cytometry analysis of thymic populations in transplanted NSG mice. $\mathbf{d}$ Absolute counts of all thymic subsets derived from the NSG experiment. e Absolute counts of all spleen subsets derived from the NSG experiment. The PBS group is shown in white, the IL-7 group at $50 \mu \mathrm{g} / \mathrm{kg}$ is shown in black, and the IL-21 at $50 \mu \mathrm{g} / \mathrm{kg}$ dose is shown in gray. All shown in vivo experiments were conducted three times with ${ }^{*} P<0.05$, ${ }^{* *} P<0.01$, and ***P $<0.0001$ and $n=10 /$ group

assessed in our studies, we presume that such increase in the pool of BM progenitors enhances thymic seeding $[60,73]$. In parallel, we demonstrated that IL-21 stimulates intrathymic $\mathrm{T}$ cell development directly by boosting the count of thymic progenitor cells while enhancing TEC recovery. The indirect effect of IL-21 on TECs is particularly important as these stromal cells guide the migration of BM-resident progenitors via the production of chemotactic gradients and mediate positive/negative selection of developing thymocytes [74]. Consistent with previous reports, our working model also stipulates the likely possibility that newly generated thymus-selected RTEs compete with peripheral donor-derived alloreactive $\mathrm{T}$ cells via a process we refer to as "homeostatic pressure" diminishing therefore the recipient's susceptibility to GVHD while ensuring proper GVT effect $[75,76]$. Our observations also hint to a possible role for IL-21 in inhibiting GVHD onset through the development, activation, and/or proliferation of B10 cells.

Thymopoiesis is a complex multilayered process with various factors at play [74]. Of all cytokines involved in $\mathrm{T}$ cell biology, IL-7 remains the central growth factor due to its role in the development, survival, and homeostatic proliferation of $\mathrm{T}$ cells [48]. Based on these properties, it was extensively studied in the context of BMT where it was shown to exert powerful thymopoieticstimulating effects [77-89]. By directly comparing the pharmacological potential of IL-7 and IL-21 using the 


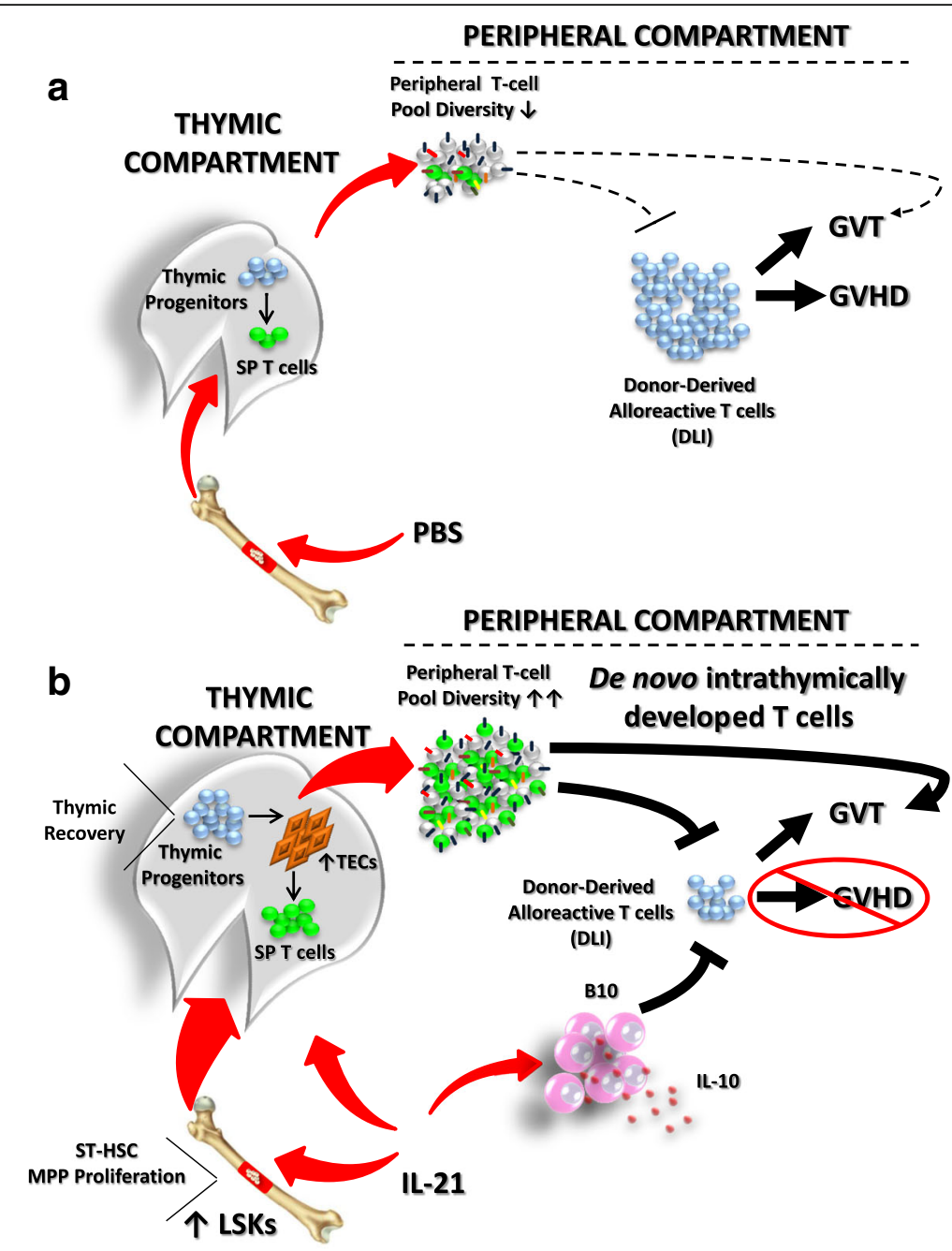

Fig. 7 Graphical abstract. a BMT pre-conditioning damages the thymus, which results in poor thymopoiesis and the generation of a restricted peripheral TCR repertoire. Consequently, the GVT effect is limited along with the appearance of GVHD induced by DLI. b Following IL-21 administration to transplanted mice, ST-HSCs and MPPs expand most likely leading to an increase in the pool of thymus-seeding progenitors. In parallel, IL-21 triggers the proliferation of thymic progenitors, which positively affects TECs resulting in accelerated recovery of a nairve T cell pool with a diversified TCR repertoire. The newly generated thymus-derived T cells promote GVT, while GVHD is controlled by homeostatic pressure on allogeneic T cells and via the action of IL-21-induced B10 cells

optimal IL-21 dose $(50 \mu \mathrm{g} / \mathrm{kg})$ previously identified, we found no significant increase in RTE output triggered by IL-7 administration to LP/J recipient mice (Fig. 1b-d). This is not surprising as IL-7 supports thymopoiesis when administered at doses ranging from 250 to $500 \mu \mathrm{g} / \mathrm{kg}$ (e.g., five- to tenfold higher than the dose used in our BMT experiments) [79, 84, 87]. It must be noted, however, that IL-21 cannot support the development of SP thymocytes in the absence of IL-7 signaling (Fig. 1g). This is consistent with our previous in vitro observations where IL-21 was found to be inert at driving $\mathrm{T}$ cell differentiation due to its inability to trigger ERK phosphorylation in TCR-engaged DP thymocytes [35]. Thus, $\mathrm{T}$ cell reconstitution could be enhanced/ accelerated by IL-21 via the induction of BM/thymic progenitor expansion but relies exclusively on IL-7 signaling to exert its pharmacological effect.

One of the most seminal observations made in the herein study was the absence of GVHD signs in IL-21treated animals while the GVT effect was retained. This is counterintuitive as GVT is usually associated with GVHD induction [65]. Furthermore, the IL-21/IL-21R signaling axis was previously reported to exacerbate GVHD in a CD4-dependent manner involving B cell expansion and production of autoantibodies [73, 90, 91]. Our study puts at play two important factors, which may help depict the discrepancy between our observations and those reported by others. First, GVHD and GVT are usually mediated by allogeneic T cells (e.g., 
DLI) transferred along or after BMT [65]. The purpose of DLI is to provide transient protection against infectious disease while ensuring eradication of postconditioning regimen-resistant cancer cells [59]. As $\mathrm{T}$ cell development is severely delayed following allogeneic BMT, donor-derived alloreactive $\mathrm{T}$ cells can expand in lymphopenic recipients consequently increasing recipients' susceptibility to GVHD [75, 76, 92-94]. Under these circumstances, the endogenous production of any pro-inflammatory cytokine(s), including IL-21, during GVHD onset would exacerbate the magnitude of the disease [75, 76, 92, 93]. In this regard, the accelerated appearance of thymus-selected RTEs triggered by exogenous IL-21 administration would not only compete with peripheral alloreactive $\mathrm{T}$ cells to access secondary lymphoid organs, homeostatic cytokines, and self-MHC ligands impeding therefore alloreactive T cell expansion/ activation, but it will also ensure efficient immune surveillance and tumor rejection as we have observed with the P815 challenge experiment conducted in IL-21treated animals (Fig. 6). Second, GVHD could be alleviated through the concrete action of B10 cells, which were previously reported to be induced by IL-21 [38]. Interestingly, B10 cells are potent regulators of macrophages and dendritic cell function, which suggest that IL-21-induced B10 cells may contribute to GVHD inhibition by restraining monocyte and dendritic cellmediated stimulation of alloreactive $\mathrm{T}$ cells [95-99]. Although we did not directly investigate the Breg mechanism of action in our BMT models, the decreased survival rate observed in IL-21-treated LP/J mice transplanted with B cell-deficient BM supports a central role for B10 cells in alleviating GVHD (Fig. 5c, d). This prompts us to formulate the hypothesis that IL-21mediated induction of B10 cells would be beneficial for controlling GVHD in a complete MHC-mismatch model $(\mathrm{C} 57 \mathrm{BL} / 6 \rightarrow \mathrm{BALB} / \mathrm{c})$. Since the complete loss of all transplanted IL-21-treated BALB/c animals occurred within the first 3 weeks post-BMT, one can argue that the strong alloreactive response mediated by allogeneic $\mathrm{T}$ cells overrides the B10 suppressive effect. Furthermore, potent production of interferon-gamma triggered by strong alloreactivity may counterbalance B10 cell expansion in vivo [38]. Besides, the observed alloreactivity in the complete MHC-mismatch BMT model occurred faster (less than 3 weeks) than the time required for de novo B ( 3-4 weeks) and T cell development ( $\sim 5$ weeks) previously observed in $\mathrm{LP} / \mathrm{J}$ recipient mice. As for the discrepancy between our observations and the exacerbated xeno-GVHD onset observed by Wu et al. in NSG mice, two central points must be discussed: the source of DLI and the bioavailability of human IL-21. In the study by Wu et al., peripheral blood mononuclear cells containing mature $\mathrm{T}$ cells were infused instead of $\mathrm{T}$ cell- depleted CB. In this context, mature $\mathrm{B}$ and $\mathrm{T}$ cells would certainly promote a superior and faster xenoreactivity in NSG mice leading consequently to xenoGVHD. Second, human IL-21 was undetectable in peripheral blood of hydrodynamically transfected NSG mice beyond 5 days. As we administered human IL21 over 2 weeks, we presume based on our LP/J observations that our approach ensures higher de novo $\mathrm{T}$ cell development with the potential induction of IL-21-induced human B10 cells, thus significantly improving NSG survival. Although evidence suggests that both positive and negative selection can occur in NSG mice $[40,100]$, we cannot preclude the possibility of xeno-GVHD development in NSG mice beyond 16 weeks post-transplantation. Additional mechanistic studies are therefore warranted to further demystify IL-21's mode of action in NSG mice.

\section{Conclusions}

In summary, our study clearly establishes a role for IL-21 in immune recovery following BMT, where it acts as a regulator of $\mathrm{BM}$ progenitor expansion as well as on the earliest phases of intrathymic $\mathrm{T}$ cell development and recovery of the stromal compartment. Its ability to simultaneously affect the BM and thymic compartments while repressing alloreactive $\mathrm{T}$ cells gives it an advantageous edge over currently tested therapies. Although our studies suggest that IL-21 could be exploited as an immunotherapeutic agent for the restoration of essential immune system functioning following ablative therapy, its impact on inducing/promoting autoimmune diseases in BMT patients remains elusive. Therefore, future pre-clinical and clinical trials should foresee the use of human IL-21 to determine its safety and efficacy in facilitating immune recovery post-BMT.

\section{Additional file}

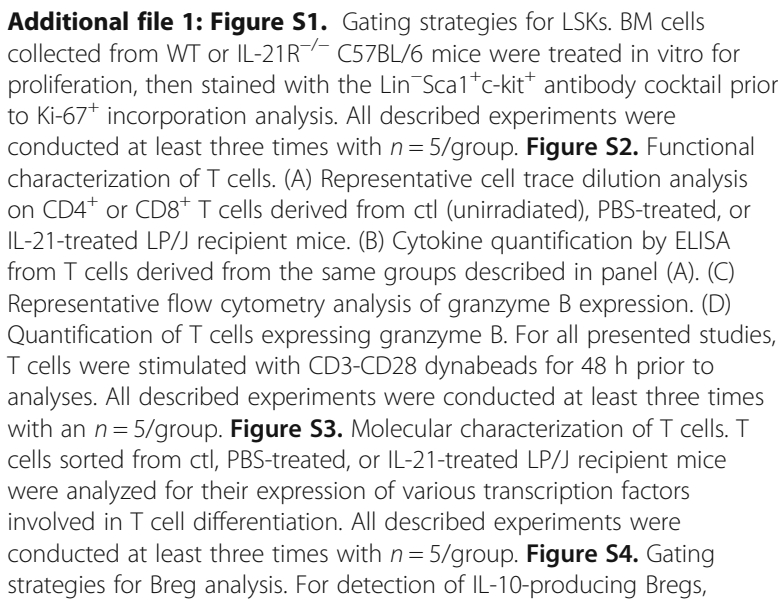


CD19+ B cells were first isolated from spleens of treated mice (isotype shown by the filled gray histogram), then stained after in vitro treatment with CD1d and CD5 antibodies. The B cell subset CD1dhiCD5 ${ }^{+}$ was gated prior to IL-10 assessment by intracellular staining. All described experiments were conducted at least three times with $n=5 /$ group. (PDF $2111 \mathrm{~kb})$

\section{Abbreviations}

B10: IL-10 producing regulatory B cells; BM: Bone marrow; BMT: Bone marrow transplantation; CB: Cord blood; DLI: Donor lymphocyte infusion; DN: Double-negative; DP: Double-positive; GVHD: Graft-versus-host-disease; GVT: Graft-versus-tumor; HSC: Hematopoietic stem cells; IL: Interleukin; IL21R: IL-21 receptor; LSK: Lin ${ }^{-}$Sca ${ }^{+}{ }^{+}$- $-\mathrm{Kit}^{+}{ }^{+}$LTT-HSCs: Long-term hematopoietic stem cells; MHC: Major histocompatibility complex; MPP: Multipotent progenitors; RTE: Recent thymic emigrant; SP: Single-positive; ST-HSCs: Shortterm hematopoietic stem cells; TCR: T cell receptor; TEC: Thymic epithelial cell; Tregs: Regulatory T cells; WT: Wild-type

\section{Acknowledgements}

We are grateful to the Institute for Research in Immunology and Cancer flow cytometry, genomics, and animal care facility staff for their assistance.

\section{Funding}

This work was supported by the Canadian Cancer Society (Innovation Grant \#2013-701623; the Louisa Gale Scholar), the Cole Foundation, the Cancer Research Society (OG2016-\#21012; for the human IL-21 work), and the Benoit Gagnon Research Fund. Aurélie Tormo holds a Cole Foundation Post-Doctoral Fellowship. Moutih Rafei holds a Fonds de la Recherche en Santé du Québec Junior II Award.

\section{Availability of data and materials}

All data generated or analyzed during this study are included in this published article and its supplementary information files.

\section{Authors' contributions}

AT designed most of the study, carried out most of the experiments, analyzed the data, and prepared the following figures: 1, 2a-e, 3, 4, 5a, b, e, and $6 \mathrm{~b}-\mathrm{e}$. FK, YC, EAC, RK, BN, and HW assisted with some experiments and contributed to the data analysis and manuscript preparation. MR designed the study, discussed the results with all authors, and wrote the manuscript. All authors approved this manuscript.

\section{Competing interests}

The authors declare that they have no competing interests.

\section{Consent for publication}

Not applicable.

\section{Ethics approval and consent to participate}

Animal protocols were approved by the Animal Care Committee of Université de Montréal. Ethics approval for the use of human CB was granted from the Ste-Justine human ethical board.

\section{Publisher's Note}

Springer Nature remains neutral with regard to jurisdictional claims in published maps and institutional affiliations.

\section{Author details}

${ }^{1}$ The Department of Pharmacology and Physiology, Université de Montréal, 2900 Edouard-Montpetit BLVD, Montréal, Québec H3T 1J4, Canada. The Department of Microbiology, Infectious Diseases and Immunology, Université de Montréal, 2900 Edouard-Montpetit BLVD, Montréal, Québec H3T 1J4, Canada. ${ }^{3}$ The Department of Microbiology and Immunology, McGill University, 3775 University Street, Montréal, Québec H3A 2B4, Canada.
Received: 16 February 2017 Accepted: 6 June 2017

Published online: 14 June 2017

\section{References}

1. Wils EJ, Cornelissen JJ. Thymopoiesis following allogeneic stem cell transplantation: new possibilities for improvement. Blood Rev. 2005:19:89-98.

2. Williams KM, Gress RE. Immune reconstitution and implications for immunotherapy following haematopoietic stem cell transplantation. Best Pract Res Clin Haematol. 2008;21:579-96.

3. Porter $\mathrm{DL}$, June $\mathrm{CH}$. T-cell reconstitution and expansion after hematopoietic stem cell transplantation: 'T' it up! Bone Marrow Transplant. 2005:35:935-42.

4. Novitzky N, Davison GM. Immune reconstitution following hematopoietic stem-cell transplantation. Cytotherapy. 2001;3:211-20.

5. Geddes M, Storek J. Immune reconstitution following hematopoietic stem-cell transplantation. Best Pract Res Clin Haematol. 2007;20:329-48.

6. Dudakov JA, van den Brink MR. Greater than the sum of their parts: combination strategies for immune regeneration following allogeneic hematopoietic stem cell transplantation. Best Pract Res Clin Haematol. 2011;24:467-76

7. Chidgey AP, Seach N, Dudakov J, Hammett MV, Boyd RL. Strategies for reconstituting and boosting $T$ cell-based immunity following haematopoietic stem cell transplantation: pre-clinical and clinical approaches. Semin Immunopathol. 2008;30:457-77.

8. Petersen SL, Ryder LP, Bjork P, Madsen HO, Heilmann C, Jacobsen N, Sengelov H, Vindelov LL. A comparison of T-, B- and NK-cell reconstitution following conventional or nonmyeloablative conditioning and transplantation with bone marrow or peripheral blood stem cells from human leucocyte antigen identical sibling donors. Bone Marrow Transplant. 2003;32:65-72.

9. Maris M, Boeckh M, Storer B, Dawson M, White K, Keng M, Sandmaier B, Maloney D, Storb R, Storek J. Immunologic recovery after hematopoietic cell transplantation with nonmyeloablative conditioning. Exp Hematol. 2003;31:941-52

10. Kalwak K, Gorczynska E, Toporski J, Turkiewicz D, Slociak M, Ussowicz M, Latos-Grazynska E, Krol M, Boguslawska-Jaworska J, Chybicka A. Immune reconstitution after haematopoietic cell transplantation in children: immunophenotype analysis with regard to factors affecting the speed of recovery. Br J Haematol. 2002;118:74-89.

11. Porrata LF, Litzow MR, Tefferi A, Letendre L, Kumar S, Geyer SM, Markovic SN. Early lymphocyte recovery is a predictive factor for prolonged survival after autologous hematopoietic stem cell transplantation for acute myelogenous leukemia. Leukemia. 2002;16:1311-8.

12. Porrata LF, Ingle JN, Litzow MR, Geyer S, Markovic SN. Prolonged survival associated with early lymphocyte recovery after autologous hematopoietic stem cell transplantation for patients with metastatic breast cancer. Bone Marrow Transplant. 2001;28:865-71.

13. Porrata LF, Gertz MA, Inwards DJ, Litzow MR, Lacy MQ, Tefferi A, Gastineau DA, Dispenzieri A, Ansell SM, Micallef IN, et al. Early lymphocyte recovery predicts superior survival after autologous hematopoietic stem cell transplantation in multiple myeloma or non-Hodgkin lymphoma. Blood. 2001;98:579-85.

14. Lucas KG, Small TN, Heller G, Dupont B, O'Reilly RJ. The development of cellular immunity to Epstein-Barr virus after allogeneic bone marrow transplantation. Blood. 1996:87:2594-603.

15. Parkman R, Cohen G, Carter SL, Weinberg Kl, Masinsin B, Guinan E, Kurtzberg J, Wagner JE, Kernan NA. Successful immune reconstitution decreases leukemic relapse and improves survival in recipients of unrelated cord blood transplantation. Biol Blood Marrow Transplant. 2006;12:919-27.

16. Porrata LF, Inwards DJ, Micallef IN, Ansell SM, Geyer SM, Markovic SN Early lymphocyte recovery post-autologous haematopoietic stem cell transplantation is associated with better survival in Hodgkin's disease. Br J Haematol. 2002:117:629-33.

17. Savani BN, Rezvani K, Mielke S, Montero A, Kurlander R, Carter CS, Leitman S, Read EJ, Childs R, Barrett AJ. Factors associated with early molecular remission after $T$ cell-depleted allogeneic stem cell transplantation for chronic myelogenous leukemia. Blood. 2006;107: 1688-95. 
18. Krause H, Hebart H, Jahn G, Muller CA, Einsele H. Screening for CMVspecific $T$ cell proliferation to identify patients at risk of developing late onset CMV disease. Bone Marrow Transplant. 1997;19:1111-6.

19. Storek J, Espino G, Dawson MA, Storer B, Flowers ME, Maloney DG. Low B-cell and monocyte counts on day 80 are associated with high infection rates between days 100 and 365 after allogeneic marrow transplantation. Blood. 2000;96:3290-3.

20. Storek J, Gooley T, Witherspoon RP, Sullivan KM, Storb R. Infectious morbidity in long-term survivors of allogeneic marrow transplantation is associated with low CD4 T cell counts. Am J Hematol. 1997;54:131-8.

21. Szabolcs P, Niedzwiecki D. Immune reconstitution after unrelated cord blood transplantation. Cytotherapy. 2007;9:111-22.

22. van den Brink MR, Alpdogan O, Boyd RL. Strategies to enhance T-cell reconstitution in immunocompromised patients. Nat Rev Immunol. 2004; 4:856-67.

23. Joao C, Porrata LF, Inwards DJ, Ansell SM, Micallef IN, Johnston PB, Gastineau DA, Markovic SN. Early lymphocyte recovery after autologous stem cell transplantation predicts superior survival in mantle-cell lymphoma. Bone Marrow Transplant. 2006;37:865-71.

24. Porrata LF, Ristow K, Witzig TE, Tuinistra N, Habermann TM, Inwards DJ, Ansell SM, Micallef IN, Johnston PB, Markovic SN. Absolute lymphocyte count predicts therapeutic efficacy and survival at the time of radioimmunotherapy in patients with relapsed follicular lymphomas. Leukemia. 2007;21:2554-6.

25. Mangel J, Leitch HA, Connors JM, Buckstein R, Imrie K, Spaner D, Crump M Pennell N, Boudreau A, Berinstein NL. Intensive chemotherapy and autologous stem-cell transplantation plus rituximab is superior to conventional chemotherapy for newly diagnosed advanced stage mantlecell lymphoma: a matched pair analysis. Ann Oncol. 2004;15:283-90

26. Brugger W, Hirsch J, Grunebach F, Repp R, Brossart P, Vogel W, Kopp HG, Manz MG, Bitzer M, Schlimok G, et al. Rituximab consolidation after highdose chemotherapy and autologous blood stem cell transplantation in follicular and mantle cell lymphoma: a prospective, multicenter phase II study. Ann Oncol. 2004;15:1691-8.

27. Spolski R, Leonard WJ. Interleukin-21: basic biology and implications for cancer and autoimmunity. Annu Rev Immunol. 2008;26:57-79.

28. Korn T, Bettelli E, Gao W, Awasthi A, Jager A, Strom TB, Oukka M, Kuchroo VK. IL-21 initiates an alternative pathway to induce proinflammatory $T(H) 17$ cells. Nature. 2007:448:484-7.

29. Vosshenrich CA, Ranson T, Samson SI, Corcuff E, Colucci F, Rosmaraki EE, Di Santo JP. Roles for common cytokine receptor gamma-chain-dependent cytokines in the generation, differentiation, and maturation of NK cell precursors and peripheral NK cells in vivo. J Immunol. 2005;174:1213-21.

30. Li Y, Bleakley M, Yee C. IL-21 influences the frequency, phenotype, and affinity of the antigen-specific CD8 T cell response. J Immunol. 2005;175: 2261-9.

31. Nurieva $R$, Yang $X O$, Martinez $G$, Zhang $Y$, Panopoulos $A D$, Ma L, Schluns $K$ Tian Q, Watowich SS, Jetten AM, Dong C. Essential autocrine regulation by IL-21 in the generation of inflammatory T cells. Nature. 2007:448:480-3.

32. Ozaki K, Spolski R, Feng CG, Qi CF, Cheng J, Sher A, Morse 3rd HC, Liu C, Schwartzberg PL, Leonard WJ. A critical role for IL-21 in regulating immunoglobulin production. Science. 2002;298:1630-4.

33. Ozaki K, Hishiya A, Hatanaka K, Nakajima H, Wang G, Hwu P, Kitamura T, Ozawa K, Leonard WJ, Nosaka T. Overexpression of interleukin 21 induces expansion of hematopoietic progenitor cells. Int J Hematol. 2006;84:224-30.

34. Simard N, Konforte D, Tran AH, Esufali J, Leonard WJ, Paige CJ. Analysis of the role of $\mathrm{IL}-21$ in development of murine $B$ cell progenitors in the bone marrow. J Immunol. 2011;186:5244-53.

35. Rafei M, Rouette A, Brochu S, Vanegas JR, Perreault C. Differential effects of gammac cytokines on postselection differentiation of CD8 thymocytes. Blood. 2013;121:107-17.

36. Rafei M, Dumont-Lagace M, Rouette A, Perreault C. Interleukin-21 accelerates thymic recovery from glucocorticoid-induced atrophy. PLoS One. 2013;8:e72801.

37. Al-Chami E, Tormo A, Pasquin S, Kanjarawi R, Ziouani S, Rafei M. Interleukin-21 administration to aged mice rejuvenates their peripheral Tcell pool by triggering de novo thymopoiesis. Aging Cell. 2016;15:349-60.

38. Yoshizaki A, Miyagaki T, DiLillo DJ, Matsushita T, Horikawa M, Kountikov El, Spolski R, Poe JC, Leonard WJ, Tedder TF. Regulatory B cells control T-cell autoimmunity through IL-21-dependent cognate interactions. Nature. 2012;491:264-8.
39. Tanaka S, Saito Y, Kunisawa J, Kurashima Y, Wake T, Suzuki N, Shultz LD, Kiyono H, Ishikawa F. Development of mature and functional human myeloid subsets in hematopoietic stem cell-engrafted NOD/SCID/ IL2rgammaKO mice. J Immunol. 2012;188:6145-55.

40. Shultz LD, Lyons BL, Burzenski LM, Gott B, Chen X, Chaleff S, Kotb M, Gillies SD, King M, Mangada J, et al. Human lymphoid and myeloid cell development in NOD/LtSz-scid IL2R gamma null mice engrafted with mobilized human hemopoietic stem cells. J Immunol. 2005;174:6477-89.

41. Shultz LD, Ishikawa F, Greiner DL. Humanized mice in translational biomedical research. Nat Rev Immunol. 2007;7:118-30.

42. Boursalian TE, Golob J, Soper DM, Cooper CJ, Fink PJ. Continued maturation of thymic emigrants in the periphery. Nat Immunol. 2004;5:418-25.

43. Hazenberg MD, Verschuren MC, Hamann D, Miedema F, van Dongen JJ. T cell receptor excision circles as markers for recent thymic emigrants: basic aspects, technical approach, and guidelines for interpretation. J Mol Med (Berl). 2001;79:631-40.

44. Hazenberg MD, Otto SA, de Pauw ES, Roelofs H, Fibbe WE, Hamann D, Miedema F. T-cell receptor excision circle and T-cell dynamics after allogeneic stem cell transplantation are related to clinical events. Blood. 2002;99:3449-53.

45. Hazenberg MD, Borghans JA, de Boer RJ, Miedema F. Thymic output: a bad TREC record. Nat Immunol. 2003;4:97-9.

46. Rafei M, Hardy MP, Williams P, Vanegas JR, Forner KA, Dulude G, Labrecque N, Galipeau J, Perreault C. Development and function of innate polyclonal TCRalphabeta+ CD8+ thymocytes. J Immunol. 2011;187:3133-44.

47. Moran AE, Holzapfel KL, Xing Y, Cunningham NR, Maltzman JS, Punt J, Hogquist KA. T cell receptor signal strength in Treg and iNKT cell development demonstrated by a novel fluorescent reporter mouse. J Exp Med. 2011;208:1279-89.

48. Mackall CL, Fry TJ, Gress RE. Harnessing the biology of IL-7 for therapeutic application. Nat Rev Immunol. 2011;11:330-42.

49. Zlotoff DA, Sambandam A, Logan TD, Bell JJ, Schwarz BA, Bhandoola A. CCR7 and CCR9 together recruit hematopoietic progenitors to the adult thymus. Blood. 2010;115:1897-905.

50. Krueger A, Willenzon S, Lyszkiewicz M, Kremmer E, Forster R. CC chemokine receptor 7 and 9 double-deficient hematopoietic progenitors are severely impaired in seeding the adult thymus. Blood. 2010;115:1906-12.

51. Zlotoff DA, Zhang SL, De Obaldia ME, Hess PR, Todd SP, Logan TD, Bhandoola A. Delivery of progenitors to the thymus limits T-lineage reconstitution after bone marrow transplantation. Blood. 2011;118:1962-70.

52. Zlotoff DA, Schwarz BA, Bhandoola A. The long road to the thymus: the generation, mobilization, and circulation of T-cell progenitors in mouse and man. Semin Immunopathol. 2008;30:371-82.

53. Zlotoff DA, Bhandoola A. Hematopoietic progenitor migration to the adult thymus. Ann N Y Acad Sci. 2011;1217:122-38.

54. Zhang SL, Bhandoola A. Trafficking to the thymus. Curr Top Microbiol Immunol. 2014;373:87-111.

55. Yang Q, Bhandoola A. Decoding HSC heterogeneity. Blood. 2012;119:4819-20.

56. Chi AW, Chavez A, Xu L, Weber BN, Shestova O, Schaffer A, Wertheim G, Pear WS, Izon D, Bhandoola A. Identification of Flt3(+)CD150(-) myeloid progenitors in adult mouse bone marrow that harbor $\mathrm{T}$ lymphoid developmental potential. Blood. 2011;118:2723-32.

57. Bhandoola A, von Boehmer H, Petrie HT, Zuniga-Pflucker JC. Commitment and developmental potential of extrathymic and intrathymic T cell precursors: plenty to choose from. Immunity. 2007;26:678-89.

58. Bell JJ, Bhandoola A. The earliest thymic progenitors for T cells possess myeloid lineage potential. Nature. 2008;452:764-7.

59. Cabezas-Wallscheid N, Klimmeck D, Hansson J, Lipka DB, Reyes A, Wang Q, Weichenhan D, Lier A, von Paleske L, Renders $S$, et al. Identification of regulatory networks in HSCs and their immediate progeny via integrated proteome, transcriptome, and DNA methylome analysis. Cell Stem Cell. 2014;15:507-22

60. Chen BJ, Cui X, Sempowski GD, Domen J, Chao NJ. Hematopoietic stem cell dose correlates with the speed of immune reconstitution after stem cell transplantation. Blood. 2004;103:4344-52.

61. Liu C, Chen BJ, Deoliveira D, Sempowski GD, Chao NJ, Storms RW. Progenitor cell dose determines the pace and completeness of engraftment in a xenograft model for cord blood transplantation. Blood. 2010;116:5518-27.

62. Wils EJ, Braakman E, Verjans GM, Rombouts EJ, Broers AE, Niesters HG, Wagemaker G, Staal FJ, Lowenberg B, Spits H, Cornelissen JJ. Flt3 ligand 
expands lymphoid progenitors prior to recovery of thymopoiesis and accelerates $T$ cell reconstitution after bone marrow transplantation. J Immunol. 2007;178:3551-7.

63. Al-Chami $\mathrm{E}$, Tormo A, Khodayarian F, Rafei M. Therapeutic utility of the newly discovered properties of interleukin-21. Cytokine. 2016;82:33-7.

64. Attridge K, Wang CJ, Wardzinski L, Kenefeck R, Chamberlain JL, Manzotti C, Kopf M, Walker LS. IL-21 inhibits T cell IL-2 production and impairs Treg homeostasis. Blood. 2012;119:4656-64.

65. Jamil MO, Mineishi S. State-of-the-art acute and chronic GVHD treatment. Int J Hematol. 2015;101:452-66.

66. Gelebart P, Zak Z, Anand M, Dien-Bard J, Amin HM, Lai R. Interleukin-21 effectively induces apoptosis in mantle cell lymphoma through a STAT1-dependent mechanism. Leukemia. 2009;23:1836-46.

67. Sarosiek KA, Malumbres R, Nechushtan H, Gentles AJ, Avisar E, Lossos IS. Novel IL-21 signaling pathway up-regulates C-Myc and induces apoptosis of diffuse large B-cell lymphomas. Blood. 2010;115:570-80.

68. Carlyle JR, Zuniga-Pflucker JC. Requirement for the thymus in alphabeta T lymphocyte lineage commitment. Immunity. 1998;9:187-97.

69. Jamieson BD, Douek DC, Killian S, Hultin LE, Scripture-Adams DD, Giorgi JV, Marelli D, Koup RA, Zack JA. Generation of functional thymocytes in the human adult. Immunity. 1999;10:569-75.

70. Zinkernagel RM, Althage A. On the role of thymic epithelium vs. bone marrow-derived cells in repertoire selection of T cells. Proc Natl Acad Sci U S A. 1999:96:8092-7.

71. Dooley J, Liston A. Molecular control over thymic involution: from cytokines and microRNA to aging and adipose tissue. Eur J Immunol. 2012;42:1073-9.

72. Gruver AL, Sempowski GD. Cytokines, leptin, and stress-induced thymic atrophy. J Leukoc Biol. 2008;84:915-23.

73. Wu X, Tan Y, Xing Q, Wang S. IL-21 accelerates xenogeneic graft-versus-host disease correlated with increased B-cell proliferation. Protein Cell. 2013:4:863-71.

74. Takahama Y. Journey through the thymus: stromal guides for T-cell development and selection. Nat Rev Immunol. 2006:6:127-35.

75. King C, llic A, Koelsch K, Sarvetnick N. Homeostatic expansion of T cells during immune insufficiency generates autoimmunity. Cell. 2004;117:265-77.

76. Moses CT, Thorstenson KM, Jameson SC, Khoruts A. Competition for self ligands restrains homeostatic proliferation of naive CD4 T cells. Proc Natl Acad Sci U S A. 2003;100:1185-90.

77. Storek J, Gillespy 3rd T, Lu H, Joseph A, Dawson MA, Gough M, Morris J, Hackman RC, Horn PA, Sale GE, et al. Interleukin-7 improves CD4 T-cell reconstitution after autologous CD34 cell transplantation in monkeys. Blood. 2003;101:4209-18

78. Perales MA, Goldberg JD, Yuan J, Koehne G, Lechner L, Papadopoulos EB, Young JW, Jakubowski AA, Zaidi B, Gallardo H, et al. Recombinant human interleukin-7 (CYT107) promotes T-cell recovery after allogeneic stem cell transplantation. Blood. 2012;120:4882-91.

79. Mackall CL, Fry TJ, Bare C, Morgan P, Galbraith A, Gress RE. IL-7 increases both thymic-dependent and thymic-independent T-cell regeneration after bone marrow transplantation. Blood. 2001;97:1491-7.

80. Li A, Zhang Q, Jiang J, Yuan G, Feng Y, Hao J, Li C, Gao X, Wang G, Xie S. Co-transplantation of bone marrow stromal cells transduced with IL-7 gene enhances immune reconstitution after allogeneic bone marrow transplantation in mice. Gene Ther. 2006;13:1178-87.

81. Gasnault J, de Goer de Herve MG, Michot JM, Hendel-Chavez H, Seta V, Mazet AA, Croughs T, Stankoff B, Bourhis JH, Lambotte O, et al. Efficacy of recombinant human interleukin 7 in a patient with severe lymphopeniarelated progressive multifocal leukoencephalopathy. Open Forum Infect Dis. 2014;1:ofu074.

82. Chung B, Min D, Joo LW, Krampf MR, Huang J, Yang Y, Shashidhar S, Brown J, Dudl EP, Weinberg Kl. Combined effects of interleukin-7 and stem cell factor administration on lymphopoiesis after murine bone marrow transplantation. Biol Blood Marrow Transplant. 2011;17:48-60.

83. Chung B, Barbara-Burnham L, Barsky L, Weinberg K. Radiosensitivity of thymic interleukin-7 production and thymopoiesis after bone marrow transplantation. Blood. 2001:98:1601-6.

84. Broers AE, Posthumus-van Sluijs SJ, Spits H, van der Holt B, Lowenberg B,

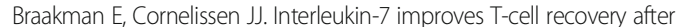
experimental T-cell-depleted bone marrow transplantation in T-cell-deficient mice by strong expansion of recent thymic emigrants. Blood. 2003;102:1534-40

85. Bolotin E, Smogorzewska M, Smith S, Widmer M, Weinberg K. Enhancement of thymopoiesis after bone marrow transplant by in vivo interleukin-7. Blood. 1996;88:1887-94.
86. Alpdogan O, Schmaltz C, Muriglan SJ, Kappel BJ, Perales MA, Rotolo JA, Halm JA, Rich BE, van den Brink MR. Administration of interleukin-7 after allogeneic bone marrow transplantation improves immune reconstitution without aggravating graft-versus-host disease. Blood. 2001;98:2256-65.

87. Alpdogan O, Muriglan SJ, Eng JM, Willis LM, Greenberg AS, Kappel BJ, van den Brink MR. IL-7 enhances peripheral T cell reconstitution after allogeneic hematopoietic stem cell transplantation. J Clin Invest. 2003;112:1095-107.

88. Abdul-Hai A, Weiss L, Ben-Yehuda A, Ergas D, Shapira MY, Slavin S. Interleukin-7 induced facilitation of immunological reconstitution of sublethally irradiated mice following treatment with alloreactive spleen cells in a murine model of B-cell leukemia/lymphoma (BCL1). Bone Marrow Transplant. 2007:40:881-9.

89. Abdul-Hai A, Or R, Slavin S, Friedman G, Weiss L, Matsa D, Ben-Yehuda A. Stimulation of immune reconstitution by interleukin-7 after syngeneic bone marrow transplantation in mice. Exp Hematol. 1996:24:1416-22.

90. Oh I, Ozaki K, Meguro A, Hatanaka K, Kadowaki M, Matsu H, Tatara R, Sato K, Iwakura Y, Nakae S, et al. Altered effector CD4+ T cell function in IL-21R-/- CD4 + T cell-mediated graft-versus-host disease. J Immunol. 2010;185:1920-6.

91. Meguro A, Ozaki K, Oh I, Hatanaka K, Matsu H, Tatara R, Sato K, Leonard WJ, Ozawa K. IL-21 is critical for GVHD in a mouse model. Bone Marrow Transplant. 2010;45:723-9.

92. Gudmundsdottir H, Turka LA. A closer look at homeostatic proliferation of CD4+ T cells: costimulatory requirements and role in memory formation. $J$ Immunol. 2001:167:3699-707.

93. Min B, Yamane H, Hu-Li J, Paul WE. Spontaneous and homeostatic proliferation of CD4 T cells are regulated by different mechanisms. J Immunol. 2005;174:6039-44.

94. Hechinger AK, Smith BA, Flynn R, Hanke K, McDonald-Hyman C, Taylor PA, Pfeifer D, Hackanson B, Leonhardt F, Prinz G, et al. Therapeutic activity of multiple common gamma-chain cytokine inhibition in acute and chronic GVHD. Blood. 2015:125:570-80.

95. Duffner UA, Maeda Y, Cooke KR, Reddy P, Ordemann R, Liu C, Ferrara JL, Teshima T. Host dendritic cells alone are sufficient to initiate acute graft-versus-host disease. J Immunol. 2004;172:7393-8.

96. Horikawa M, Minard-Colin V, Matsushita T, Tedder TF. Regulatory B cell production of IL-10 inhibits lymphoma depletion during CD20 immunotherapy in mice. J Clin Invest. 2011:121:4268-80.

97. Iwata Y, Matsushita T, Horikawa M, Dilillo DJ, Yanaba K, Venturi GM, Szabolcs PM, Bernstein SH, Magro CM, Williams AD, et al. Characterization of a rare IL-10-competent B-cell subset in humans that parallels mouse regulatory B10 cells. Blood. 2011;117:530-41.

98. Shlomchik WD, Couzens MS, Tang CB, MCNiff J, Robert ME, Liu J, Shlomchik MJ, Emerson SG. Prevention of graft versus host disease by inactivation of host antigen-presenting cells. Science. 1999;285:412-5.

99. Zhang Y, Shlomchik WD, Joe G, Louboutin JP, Zhu J, Rivera A, Giannola D, Emerson SG. APCs in the liver and spleen recruit activated allogeneic CD8+ $T$ cells to elicit hepatic graft-versus-host disease. J Immunol. 2002;169:7111-8.

100. Ishikawa F, Yasukawa M, Lyons B, Yoshida S, Miyamoto T, Yoshimoto G, Watanabe T, Akashi K, Shultz LD, Harada M. Development of functional human blood and immune systems in NOD/SCID/IL2 receptor \{gamma\} chain(null) mice. Blood. 2005:106:1565-73.

\section{Submit your next manuscript to BioMed Central and we will help you at every step:}

- We accept pre-submission inquiries

- Our selector tool helps you to find the most relevant journal

- We provide round the clock customer support

- Convenient online submission

- Thorough peer review

- Inclusion in PubMed and all major indexing services

- Maximum visibility for your research

Submit your manuscript at www.biomedcentral.com/submit 